The Canadian Mineralogist

Vol. 41, pp. 727-748 (2003)

\title{
ACCESSORY MINERALS IN THE XIHUASHAN Y-ENRICHED GRANITIC COMPLEX, SOUTHERN CHINA: A RECORD OF MAGMATIC AND HYDROTHERMAL STAGES OF EVOLUTION
}

\author{
Ru CHENG WANG ${ }^{\S}$ \\ State Key Laboratory for Mineral Deposits Research, Department of Earth Sciences, Nanjing University, \\ Nanjing 210093, People's Republic of China, and Laboratoire de Mécanisme de Transfert en Géologie, \\ Équipe de Minéralogie, UMR 5563, Université Paul Sabatier, 39, Allées Jules Guesde, F-31000 Toulouse, France
}

FRANÇOIS FONTAN

Laboratoire de Mécanisme de Transfert en Géologie, Équipe de Minéralogie, UMR 5563, Université Paul Sabatier, 39, Allées Jules Guesde, F-31000 Toulouse, France

\author{
Xiao Ming Chen, Huan HU, Chang Shi LiU and Shi Jin XU
}

State Key Laboratory for Mineral Deposits Research, Department of Earth Sciences, Nanjing University, Nanjing 210093, People's Republic of China

PHILIPPE DE PARSEVAL

Laboratoire de Mécanisme de Transfert en Géologie, Équipe de Minéralogie, UMR 5563, Université Paul Sabatier, 39, Allées Jules Guesde, F-31000 Toulouse, France

\begin{abstract}
The Xihuashan granitic complex (southern China) is mainly composed of coarse-grained porphyritic biotite granite (G-a), medium-grained porphyritic biotite granite $(\mathrm{G}-\mathrm{b})$, and medium- to fine-grained porphyritic biotite granite $(\mathrm{G}-\mathrm{c})$. The $\mathrm{G}-\mathrm{a}$ granite is characterized by monazite-(Ce) and xenotime-(Y), in addition to commonly observed zircon and uranoan thorite. In the G-b and $\mathrm{G}-\mathrm{c}$ intrusive units, monazite-(Ce) becomes very scarce, whereas Y-bearing minerals, including Y-bearing spessartine, xenotime-( $(\mathrm{Y})$, gadolinite- $(\mathrm{Y})$, fergusonite- $(\mathrm{Y})$, and yttrian fluorite (up to $15 \mathrm{wt} \% \mathrm{Y}_{2} \mathrm{O}_{3}$ ), are concentrated to various extents. Spessartine exhibits chemical zoning, which is displayed, in the core, by elevated contents of $\mathrm{Y}$ and heavy REE (HREE) (up to $2.32 \mathrm{wt} \% \mathrm{Y}_{2} \mathrm{O}_{3}$ and $1.51 \% \mathrm{HREE}_{2} \mathrm{O}_{3}$ ) and micrometric inclusions of Y-bearing minerals. Similarly, zircon from the G-b and G$\mathrm{c}$ granites contains polymineralic micro-inclusions in the core. Overall, the accessory minerals point to a magmatic environment of crystallization for the G-a granite. In contrast, the crystallization of the G-b and G-c granites involved magmatic and hydrothermal stages. The late- to postmagmatic fluid is enriched in $\mathrm{F}$ and $\mathrm{CO}_{2}$, and appeared as a result of the final oversaturation of the granitic melt in a fluid phase.
\end{abstract}

Keywords: yttrian fluorite, yttrium-bearing spessartine-almandine, xenotime-(Y), zircon, electron-microprobe data, granite, Xihuashan, China.

\section{SOMMAIRE}

Le complexe granitique de Xihuashan, dans le sud de la Chine, est principalement composé de granite porphyrique à biotite à gros grains $(\mathrm{G}-\mathrm{a})$, à grains moyens $(\mathrm{G}-\mathrm{b})$ et à grains de moyens à fins $(\mathrm{G}-\mathrm{c})$. Le granite $\mathrm{G}-\mathrm{a}$ contient, en plus du zircon et de la thorite uranifère répandus, deux minéraux accessoires: monazite-(Ce) et xénotime-(Y). Dans les granites G-b et G-c, la monazite-(Ce) devient très rare, tandis que divers minéraux à yttrium, dont spessartine, xénotime-(Y), gadolinite-(Y), et fergusonite-(Y), montrent des teneurs variables en yttrium, de même que la fluorite (jusqu'à $15 \%$ en poids de $\mathrm{Y}_{2} \mathrm{O}_{3}$ ). La spessartine présente une zonation chimique, qui se caractérise au coeur par des concentrations élevées en $\mathrm{Y}$ et terres rares lourdes (jusqu'à $2.32 \% \mathrm{Y}_{2} \mathrm{O}_{3}$ et $1.51 \%$ des oxydes de terres rares lourdes, en poids) et des inclusions micrométriques de minéraux yttrifères. De même, le centre des cristaux de zircon des granites $\mathrm{G}-\mathrm{b}$ et $\mathrm{G}-\mathrm{c}$ contient aussi de petites inclusions de phases yttrifères. Ces

§ E-mail address: rcwang@nju.edu.cn, ru-cheng.wang@cict.fr 
observations de minéraux accessoires indiquent un milieu magmatique pour le granite G-a, tandis que les granites G-b et G-c ont cristallisé au cours de stades magmatique et hydrothermal. Ces fluides magmatiques tardifs à post-magmatiques étaient enrichis en $\mathrm{F}$ et $\mathrm{CO}_{2}$, qui proviennent d'une sursaturation finale du magma granitique en phase fluide.

Mots-clés: fluorite yttrifère, spessartine-almandin yttrifère, xénotime-(Y), zircon, granite, Xihuashan, Chine.

\section{INTRODUCTION}

Accessory minerals are considered the principal hosts of high-field-strength elements (HFSE) and rareearth elements $(R E E)$ in granitic melts. Many investigations have shown that assemblages of accessory minerals are compositionally more variable in granitic rocks than major minerals. Their crystallization is generally sensitive to parameters like temperature, $f\left(\mathrm{O}_{2}\right)$, and melt composition (e.g., Cuney \& Friederich 1987, Rapp \& Watson 1986), and their compositional evolution typically continues below the solidus. Therefore, accessory minerals in a granitic rock can serve as a sensitive indicator of crystallization histories at the magmatic stage (Robinson \& Miller 1999, Dahlquist 2001, Wang et al. 2001), and during postmagmatic events.

South China is an important area of peraluminous granitic activity associated with $\mathrm{W}-\mathrm{Sn}-\mathrm{Nb}-\mathrm{Ta}$ mineralization (Hu et al. 1984). Examples of mineralized granites include the Xihuashan granite, Jiangxi (W deposit, Maruéjol et al. 1990), the Xianghualing granite, Hunan (Sn-Ta-Li deposit, Zhu \& Liu 1990), the Yichun granite, Jiangxi (Nb-Ta-Li deposit, Yin et al. 1995), and the Limu granite, Guangxi (Ta-Sn deposit, Zhu et al. 2001). Of these plutons, most are depleted in $\mathrm{Y}$ and the REE ( $<2 \mathrm{ppm} \mathrm{Y,} \mathrm{<30} \mathrm{ppm} \mathrm{\Sigma REE);} \mathrm{however,} \mathrm{the}$ Xihuashan granite is exceptionally rich in $R E E$ and particularly in $\mathrm{Y}(98<\Sigma R E E<322 \mathrm{ppm} ; 91<\mathrm{Y}<170$ $\mathrm{ppm})$. Correspondingly, a series of Y-bearing phosphates, silicates, fluorides, and niobotantalates, and also other associated accessory minerals of $\mathrm{Zr}, \mathrm{U}$, Th and $\mathrm{Nb}$, are present in the Xihuashan granitic complex, and motivated our study. Apart from results of a few wetchemical analyses and partial electron-microprobe analyses of rock-forming and accessory minerals, virtually no data exist on the mineralogy of the Xihuashan granites. We here present a detailed description of a complex assemblage of minerals containing $\mathrm{Y}, R E E, \mathrm{Zr}$, $\mathrm{Nb}, \mathrm{W}, \mathrm{U}$, and Th minerals, and provide a discussion on their response to magmatic and hydrothermal evolution during the crystallization and cooling of the pluton.

\section{Geological Setting}

The Xihuashan district is an important part of the Gannan (southern Jiangxi) tungsten metallogenic province, and is world-famous for its large vein-type tungsten deposits. They were discovered in the early 1930s in the endo- and exocontact zones of the Xihuashan granitic complex (Hsu 1943). Mining of quartz-ferberitetype ores started in 1935. The metallogeny of the deposits and the petrology of associated granites were described by Hsu (1943), Le Bel et al. (1984), McKee et al. (1987), Giuliani et al. (1988), Maruéjol et al. (1990) and Shen et al. (1994).

The Xihuashan granitic complex belongs to the Nanling Yanshanian (Cretaceous-Jurassic) orogenic metallogenic belt; it is located $10 \mathrm{~km}$ northeast of Dayu city (Fig. 1). It crops out over an area of about $20 \mathrm{~km}^{2}$ and was emplaced in Cambrian sandstones. Exploratory drilling allows us to subdivide this complex into at least three successive pulses of emplacement. The first stage $\left(\gamma_{5}{ }^{2 a}\right)$ consists of coarse-grained porphyritic biotite granite (G-a). It occurs as the outermost part of the complex, and outcrops over an area of $4.8 \mathrm{~km}^{2}$. It consists mainly of quartz, perthitic K-feldspar, oligoclase $\left(\mathrm{An}_{10-12}\right)$ and biotite. The second stage $\left(\gamma_{5}{ }^{2 b}\right)$ consists of mediumgrained porphyritic biotite granite $(\mathrm{G}-\mathrm{b})$, which is oreproducing and hosts tungsten mineralization at the Xihuashan mine. The surface exposure is about $5.2 \mathrm{~km}^{2}$. The major rock-forming minerals include quartz, perthitic K-feldspar, sodic plagioclase $\left(\mathrm{An}_{0-2}\right)$, biotite, and spessartine. The third stage $\left(\gamma_{5}^{2 \mathrm{c}}\right)$ crops out over an area of $8 \mathrm{~km}^{2}$ in the northern part of the Xihuashan complex. It is a medium- to fine-grained porphyritic biotite granite $(\mathrm{G}-\mathrm{c})$, and hosts tungsten mineralization, exploited at the Dangping mine. The major minerals are similar to those of the G-b granite, but fluorite is relatively more abundant in the $\mathrm{G}-\mathrm{b}$ granite. A fine-grained biotite granite $(\mathrm{G}-\mathrm{d})$ is considered as a sterile border of the $\gamma_{5}{ }^{2 \mathrm{c}}$ granite, and restricted to NW-SE-trending dykes in the middle part of the pluton.

Chronological studies of the Xihuashan granitic complex (K-Ar, Sm-Nd and Ar-Ar methods) gave ages of about $150 \mathrm{Ma}$ (Le Bel et al. 1984, Mc Kee et al. 1987). In Table 1, major- and selected trace-element contents of the granites at Xihuashan are shown. Values of A/CNK (defined in Table 1) for the units of the Xihuashan granitic complex range from 1.04 to 1.07 , and suggest a weakly peraluminous granite, but less strongly so than other rare-metal-enriched granites in southern China. The granite samples contain between 91 and $170 \mathrm{ppm} \mathrm{Y}$, and 98-322 ppm REE, strikingly higher than other comparable Chinese granites, and demonstrate a marked depletion in LREE from the G-a granite to the $\mathrm{G}-\mathrm{b}$ and $\mathrm{G}-\mathrm{c}$ granites. More detailed 


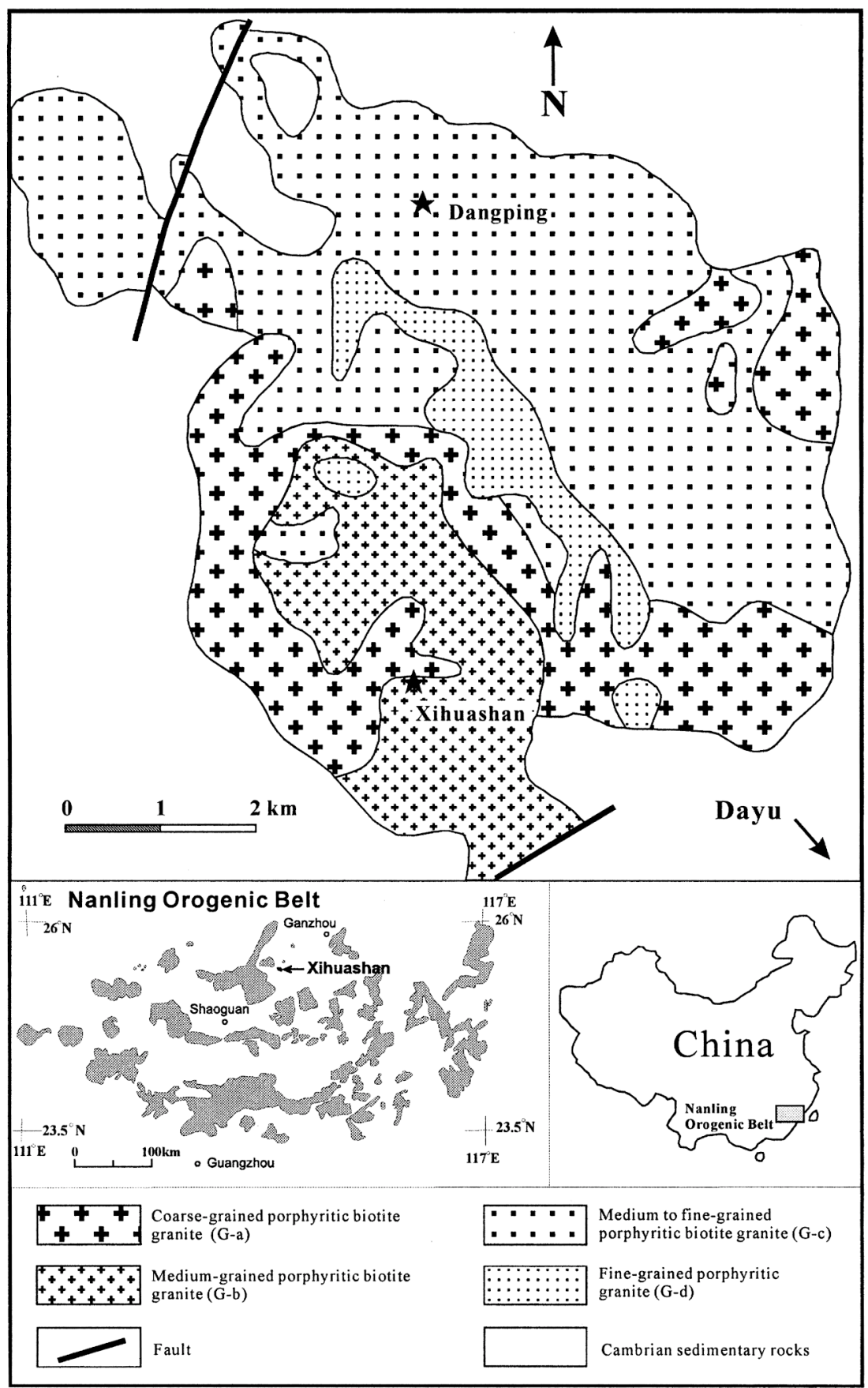

FIG. 1. Geological map of the Xihuashan granitic complex, southern China, modified after Li et al. (1986). 
petrological and geochemical information on the Xihuashan granites is described in Li et al. (1986) and Maruéjol et al. (1990).

\section{Samples and Analytical Methods}

Polished thin sections of the G-a, G-b and G-c granites were initially examined using the back-scattered electron (BSE) mode with a JEOL JXA8800 electron microprobe at the Department of Earth Sciences, Nanjing University, in order to characterize the textural relationships and to define the mineral paragenesis of accessory minerals. Compositional analyses of minerals were carried out using the same electron microprobe, except for spessartine, xenotime-(Y) and monazite-(Ce), which were analyzed using a Cameca SX50 electron microprobe at Université Paul Sabatier in Toulouse. The operating conditions for the JEOL electron-microprobe analysis were as follows for all accessory minerals except the REE minerals: acceleration voltage $20 \mathrm{kV}$, beam current $20 \mathrm{nA}$, and diameter of electron beam 1 $\mu \mathrm{m}, \mathrm{ZAF}$ correction program. The method outlined by Williams (1996) was used for analyses of the minerals of rare-earth elements. Count time of 30 seconds were used for $\mathrm{Y}, \mathrm{La}$ and $\mathrm{Ce}, 50$ seconds for Pr, Nd and Sm, and 20 seconds for $\mathrm{Eu}, \mathrm{Gd}, \mathrm{Er}$ and $\mathrm{Yb}$. Synthetic $\mathrm{Y}$ and REE pentaphosphates $\left(\mathrm{YP}_{5} \mathrm{O}_{14}\right.$ and $\left.R E E \mathrm{P}_{5} \mathrm{O}_{14}\right)$ were used as standards. The procedures of Åmli \& Griffin (1975) and Roeder (1985) were used to correct peak overlaps between some elements. Europium contents of $R E E$-bearing minerals are generally below detection limits (about at $0.02 \mathrm{wt} \% \mathrm{Eu}_{2} \mathrm{O}_{3}$ ). The operating conditions for the Cameca electron-microprobe included an acceleration voltage of $15 \mathrm{kV}$, a beam current of $20 \mathrm{nA}$, a beam diameter of $1 \mu \mathrm{m}$, and PAP correction program. Synthetic phosphates were used for measurements of REE and Y (Jarosewich \& Boatner 1991).

\section{The Compositions of the Accessory Minerals}

The accessory minerals from the Xihuashan granites were systematically studied and described as follows in the order of fluoride, silicate, phosphate, carbonate, oxide and tungstate.

\section{Fluorite}

Fluorite is restricted to the $\mathrm{G}-\mathrm{b}$ and $\mathrm{G}-\mathrm{c}$ granites. We recognize three generations. The first (Fluorite $\mathrm{I}$ ) is rare, but is invariably associated with spessartine (Fig. 2a); the second (Fluorite II) is associated with crystals of zircon and thorite (Fig. 2b), and located predominantly as intergranular minerals among rock-forming minerals such as feldspar, quartz, biotite and muscovite. The third (Fluorite III) coexists with synchysite-(Y) (Fig. 2c), and characteristically surround grains of fluorite I (Fig. 2a).
Representative results of electron-microprobe analyses are shown in Table 2. Fluorite I is compositionally unusual in that it contains more than $8 \mathrm{wt} \% \mathrm{Y}_{2} \mathrm{O}_{3}$, and up to $15 \mathrm{wt} \%$ (Sample B, Table 2). Concentrations of $R E E_{2} \mathrm{O}_{3}$ vary from 2.42 to $7.87 \mathrm{wt} \%$. Calculation of structural formulae gives up to 16 mole $\%$ of a $(\mathrm{Y}, R E E) \mathrm{F}_{3}$ component in solid solution in fluorite, suggestive of an yttrian fluorite $\left(\mathrm{Ca}_{1-x} \mathrm{Y}_{x}\right) \mathrm{F}_{2+x}$. Fluorite II has a nearly pure composition, with $<0.1 \mathrm{wt} \% \mathrm{Y}_{2} \mathrm{O}_{3}$, although it is commonly associated with Y-bearing minerals including xenotime-(Y) and fergusonite-(Y). Fluorite III has variable $\mathrm{Y}$ contents, but invariably lower than $4 \mathrm{wt} \%$. The REE contents in fluorite II and fluorite III are generally below the detection limits.

Back-scattered electron images show clearly that fluorite I is typically rimmed by fluorite III and synchysite-(Y) (Fig. 2a). Textural evidence suggests that the primary yttrian fluorite gave way to Y-poor fluorite $\left(<4 \mathrm{wt} \% \mathrm{Y}_{2} \mathrm{O}_{3}\right)$ and synchysite- $(\mathrm{Y})$ as crystallization progressed, the latter being distributed along the cleavage in the fluorite III (Fig. 2c).

TABLE 1. MAJOR- AND TRACE-ELEMENT CONTENTS OF THE XIHUASHAN GRANITIC COMPLEX AND COMPARISON WITH OTHER PERALUMNOUS RARE-ELEMENT-ENRICHED GRANITES IN SOUTHERN CHINA

\begin{tabular}{|c|c|c|c|c|c|c|c|c|c|c|}
\hline \multirow[b]{2}{*}{ Ref. } & \multicolumn{6}{|c|}{ XHS } & \multirow{2}{*}{$\begin{array}{l}\text { YS } \\
\text { (3) }\end{array}$} & \multirow{2}{*}{$\begin{array}{l}\text { LM } \\
\text { (4) }\end{array}$} & \multirow{2}{*}{$\begin{array}{l}\text { XIIL } \\
\text { (5) }\end{array}$} & \multirow{2}{*}{$\begin{array}{l}\text { DFX } \\
\text { (6) }\end{array}$} \\
\hline & $\begin{array}{l}\mathrm{G}-\mathrm{a} \\
\text { (1) }\end{array}$ & $\begin{array}{c}\mathrm{G}-\mathrm{b} \\
\text { (1) }\end{array}$ & $\begin{array}{l}\mathrm{G}-\mathrm{c} \\
\text { (1) }\end{array}$ & $\begin{array}{l}\mathrm{G}-\mathrm{a} \\
\text { (2) }\end{array}$ & $\begin{array}{l}\mathrm{G}-\mathrm{b} \\
(2)\end{array}$ & $\begin{array}{l}\text { G-c } \\
\text { (2) }\end{array}$ & & & & \\
\hline $\mathrm{SiO}_{2}$ & 74.61 & 75.74 & 74.98 & 73.00 & 76.43 & 75.65 & 71,12 & 73.55 & 72.46 & 79.90 \\
\hline $\begin{array}{l}\mathrm{PiO}_{2} \\
\mathrm{TiO}_{3}\end{array}$ & $\begin{array}{r}14.01 \\
0.10\end{array}$ & $\begin{array}{r}0.03 \\
0.03\end{array}$ & $\begin{array}{r}4.90 \\
0.05\end{array}$ & 0.14 & 0.01 & 0.06 & 0.01 & 0.02 & 0.00 & 0.02 \\
\hline $\begin{array}{l}\mathrm{Al}_{2} \mathrm{O}_{3} \\
\mathrm{He}_{2} \mathrm{O}^{\mathrm{r}}\end{array}$ & 13.32 & 13.17 & 13.55 & $\begin{array}{r}13.95 \\
1.67\end{array}$ & $\begin{array}{r}12.67 \\
0.91\end{array}$ & $\begin{array}{r}12.82 \\
0.73\end{array}$ & $\begin{array}{r}16.68 \\
0.16\end{array}$ & 14.82 & 15.76 & 13.73 \\
\hline $\begin{array}{l}\mathrm{Fe}_{2} \mathrm{O}_{3} \\
\mathrm{Fe}_{2} \mathrm{O}_{3}\end{array}$ & 0.35 & 0.26 & 0.22 & & $\begin{array}{l}0.91 \\
0.00\end{array}$ & 0.00 & & 0.17 & 0.21 & 0.76 \\
\hline $\mathrm{FeO}$ & 1.73 & 1.23 & 1.00 & & 0.00 & 0.00 & & 0.65 & 0.63 & 1.03 \\
\hline $\mathrm{MnO}$ & 0.07 & 0.10 & 0.10 & 0.07 & 0.11 & 0.09 & 0.14 & 0.13 & 0.10 & 0.09 \\
\hline $\mathrm{MgO}$ & 0.45 & 0.19 & 0.26 & 0.27 & 0.10 & 0.03 & 0.10 & 0.10 & 0.12 & 0.19 \\
\hline $\mathrm{CaO}$ & 1.19 & 0.60 & 0.79 & 1.16 & 0.46 & 0.48 & 0.19 & 0.31 & $0.1 \overline{4}$ & 0.30 \\
\hline $\mathrm{Na}_{2} \mathrm{O}$ & 3.39 & 4.11 & 3.84 & 3.32 & 3.79 & 4.09 & 4.88 & 5.02 & 5.15 & 3.84 \\
\hline $\mathrm{K}_{2} \mathrm{O}$ & 4.71 & 4.35 & 4.70 & 5.00 & 4.61 & 4.17 & 3.13 & 3.93 & 3.97 & 2.37 \\
\hline $\mathrm{P}_{7} \mathrm{O}_{5}$ & 0.05 & 0.05 & 0.05 & 0.03 & $<0.01$ & $<0.01$ & 0.36 & 0.20 & 0.01 & 0.27 \\
\hline $\mathrm{LOI}$ & & & & 1.13 & 0.14 & 0.17 & 1.61 & 0.52 & 0.73 & \\
\hline$\Gamma$ & & & & 0.37 & 0.75 & 0.71 & 1.62 & 0.66 & 1.00 & \\
\hline $\mathrm{F}=\mathrm{O}$ & & & & -0.16 & -0.06 & -0.07 & -0.68 & -0.27 & 0.42 & \\
\hline Total & 99.97 & 99.83 & 99.54 & 99.95 & 99.90 & 98.91 & 99.32 & 99.79 & 99.86 & \\
\hline $\mathrm{A} / \mathrm{CNK}$ & 1.04 & 1.05 & 1.05 & 1.07 & 1.05 & 1.06 & 1.42 & 1.13 & 1.21 & 1.45 \\
\hline $\mathrm{Y}$ & 96.8 & 142.1 & 125.8 & 91.4 & 148.3 & 169.6 & 0.49 & 0.72 & 1.15 & 1.25 \\
\hline LREE 1 & 166.7 & 45.0 & 38.6 & 128.2 & 62.9 & 38.9 & 0.44 & 2.74 & 21.9 & 3.2 \\
\hline HREE 1 & 155.2 & 157.5 & 189.9 & 38.3 & 59.4 & 57.8 & 0.29 & 1.08 & 5.2 & 1.7 \\
\hline U & & & & 22.1 & 36.9 & 31.4 & & 9.9 & & \\
\hline Th & & & & 34.7 & 28.3 & 21.1 & 2.6 & 11.5 & 0.0 & \\
\hline $\mathrm{Nb}$ & 23.5 & 52 & 21 & 14 & 31.5 & 25.5 & 48.8 & 82.6 & & 100 \\
\hline $\mathrm{Ta}$ & 5 & 20 & 30.5 & 6 & 18 & 18 & 78.2 & 75.3 & & 87 \\
\hline $\mathrm{la}$ & 200 & 165 & 10.5 & 107 & 66 & 65 & 25.4 & 32.6 & 37 & 153 \\
\hline $\mathrm{Hf}$ & 7.1 & 11.2 & 86 & & & & 4.3 & 4.0 & 2 & 15 \\
\hline
\end{tabular}

Granite plutons: XHS: Xihuashan, YS: Yashan, LM: Limu, XHL: Xianghualing, DFX: Dengfuxian. References: (1) Xu (1986), (2) Maruéjol et al. (1990), (3) Iluang et al. (2002), (4) 7hu et al. (2001), (5) Liu (1990), (6) Xu (1986). $\mathrm{Fe}_{2} \mathrm{O}_{3}{ }^{\mathrm{T}}$ : total iron (2002), (4) 7hu et al. (200 $),(5)$ Liu $(1990),(6) \mathrm{Xu}_{2}(1986)$. $\mathrm{Fe}_{2} \mathrm{O}_{3}$ : total iron
cxpressed as $\mathrm{Fe}_{2} \mathrm{O}_{3}, \mathrm{~A} / \mathrm{CNK}=\mathrm{Nl}_{2} \mathrm{O}_{3} /\left(2 \mathrm{CaO}+\mathrm{Na}_{2} \mathrm{O}-\mathrm{K}_{2} \mathrm{O}\right.$ )(molar proportions). The expressed as $\mathrm{Fe}_{2} \mathrm{O}_{3}, \mathrm{~A} / \mathrm{CNK}=\mathrm{Nl}_{2} \mathrm{O}_{3} /\left(2 \mathrm{CaO}+\mathrm{Na}_{2} \mathrm{O}+\mathrm{K}_{2} \mathrm{O}\right.$ ) (molar proportions). The
major-element composition is reported in wt $\%$, and trace-element concentrations are major-element composition is reported in wt \%, and trace-element concentrations are heavy rare-earth elements, respectively. 

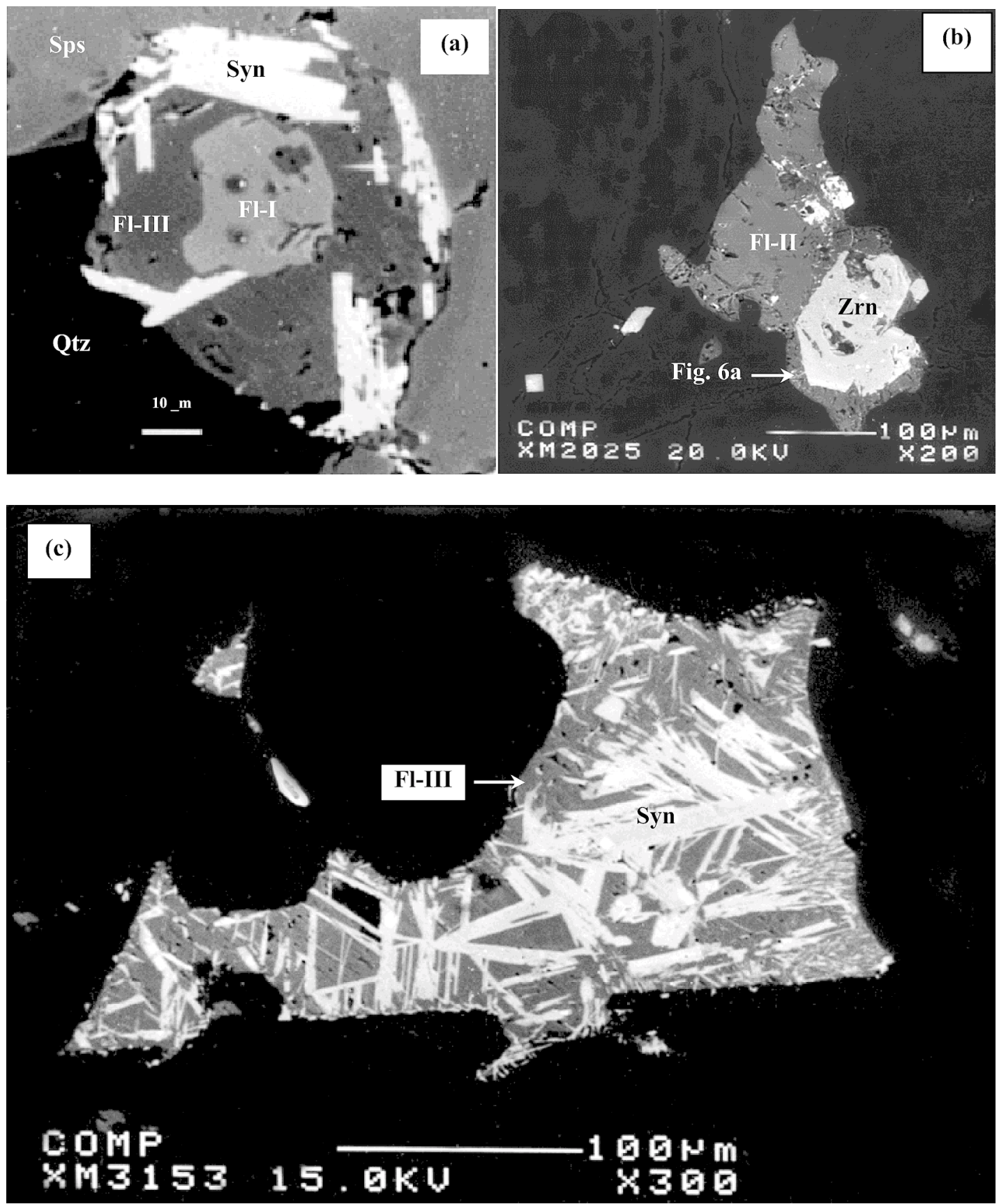

FIG. 2. Back-scattered electron images of fluorite. (a) Relic of early yttrian fluorite (Fl-I) surrounded by later fluorite III (Fl-III) and synchysite-(Y) (Syn). (b) Association of fluorite II (Fl-II) and hafnian zircon (Zrn). (c) Association of fluorite III and synchysite-(Y). Sps: spessartine, Qtz: quartz. 
TABIE 2. REPRESENTATIVE COMPOSITION OF FLUORITE AND ASSOCIATED SYNCHYSITE-(Y) FROM THE INTRUSIVE UNITS OF THE XIHUASHAN GRANITE

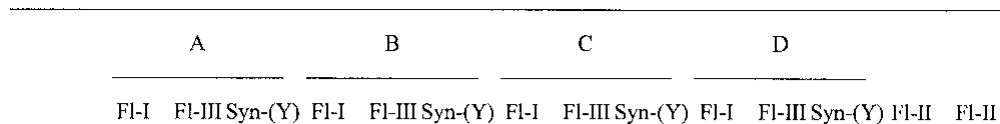

\begin{tabular}{|c|c|c|c|c|c|c|c|c|c|c|c|c|c|c|}
\hline \multicolumn{2}{|c|}{$\mathrm{Y}_{2} \mathrm{O}_{3} w t \% 12.98$} & 3.90 & 27.95 & 14.97 & 3.75 & 28.45 & 13.20 & 5.54 & 27.74 & 14.77 & 2.66 & 25.61 & 0.06 & 0.61 \\
\hline $\mathrm{La}_{2} \mathrm{O}_{3}$ & 0.48 & 0.03 & 1.64 & 0.29 & 0.02 & 1.46 & 0.41 & 0.01 & 1.32 & 0.59 & 0.00 & 3.32 & - & 0.08 \\
\hline $\mathrm{Ce}_{2}^{2} \mathrm{O}_{3}$ & 1.65 & 0.11 & 4.65 & 1.16 & 0.08 & 3.62 & 1.52 & 0.15 & 3.18 & 1.63 & 0.18 & 7.85 & - & 0.04 \\
\hline $\mathrm{Nd}_{2} \mathrm{O}_{3}$ & 0.84 & - & 2.12 & 0.71 & - & 1.85 & 0.57 & 0.02 & 1.75 & 1.19 & 0.01 & 1.91 & - & - \\
\hline $\mathrm{Sm}_{2} \mathrm{O}_{3}$ & 0.09 & - & 1.01 & 0.12 & - & 0.89 & 0.15 & - & 1.17 & 0.91 & - & 0.91 & - & - \\
\hline $\mathrm{Gd}_{2} \mathrm{O}_{3}$ & 0.49 & - & 1.96 & 0.31 & - & 1.35 & 0.10 & - & 2.16 & 0.92 & - & 1.76 & - & - \\
\hline $\mathrm{Tb}_{2} \mathrm{O}_{3}$ & 0.24 & - & 0.09 & 0.07 & - & 0.05 & 0.02 & - & 0.16 & 0.02 & - & 0.08 & - & - \\
\hline $\mathrm{Dy}_{2} \mathrm{O}_{3}$ & 0.64 & - & 1.86 & 0.12 & - & 1.79 & 0.16 & - & 2.17 & 1.18 & - & 1.67 & - & - \\
\hline $\mathrm{Ho}_{2} \mathrm{O}_{3}$ & - & - & 0.34 & - & - & 0.35 & - & - & 0.34 & 0.11 & - & 0.31 & - & - \\
\hline $\mathrm{Er}_{2} \mathrm{O}_{3}$ & - & - & 1.61 & - & - & 1.68 & - & - & 1.26 & 1.18 & - & 1.45 & - & - \\
\hline $\mathrm{Yb}_{2} \mathrm{O}_{3}$ & 0.30 & - & 1.15 & 0.15 & - & 1.06 & 0.24 & - & 0.99 & 0.14 & - & 1.04 & - & - \\
\hline $\mathrm{CaO}$ & 54.81 & 67.87 & 19.08 & 54.97 & 67.26 & 19.59 & 56.09 & 66.16 & 19.61 & 51.10 & 68.89 & 18.91 & 71.00 & 70.92 \\
\hline Total & 72.52 & 71.90 & 63.45 & 72.86 & 71.11 & 62.14 & 72.45 & 71.87 & 61.85 & 73.72 & 71.74 & 64.81 & 71.07 & 71.64 \\
\hline $\mathrm{F}$ & 46.59 & 47.90 & 4.70 & 45.22 & 47.94 & 4.70 & 46.13 & 47.95 & 5.14 & 44.92 & 48.17 & 4.09 & 48.45 & 48.23 \\
\hline $\mathrm{F}=\mathrm{O}$ & -19.57 & -20.12 & -1.97 & -18.99 & -20.13 & -1.97 & -19.38 & -20.14 & -2.16 & -18.87 & -20.23 & -1.72 & -20.40 & 20.31 \\
\hline Total & 99.55 & 99.68 & 66.18 & 99.09 & 98.91 & 64.86 & 99.21 & 99.68 & 64.83 & 99.77 & 99.68 & 67.18 & 99.12 & 99.56 \\
\hline $\mathrm{CO}_{2}(\mathrm{c}$ & & & 32.73 & & & 32.73 & & & 32.53 & & & 32.75 & & \\
\hline
\end{tabular}

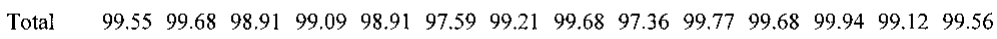

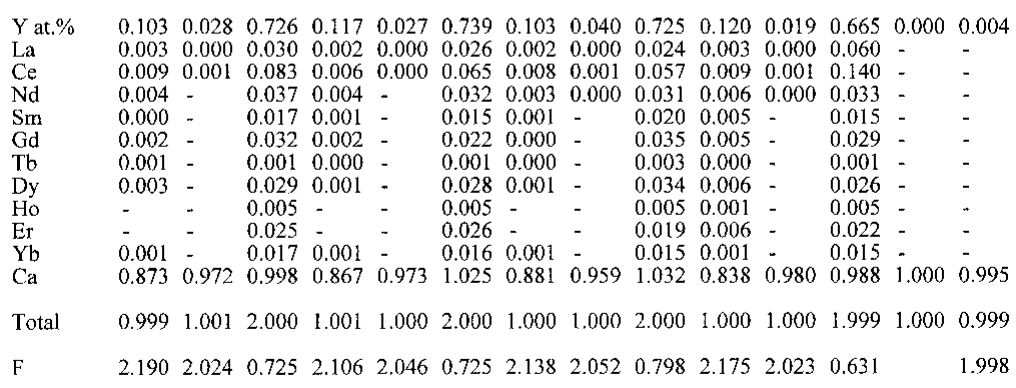

A, B C D : association of luprite I fluorite III and synchysite-( $Y$ ) in four differcnt samples. Fl-IL: association with A, B, C, D: association of fluorite I, fluorite III and synchysite-(Y) in four different samples. Fl-II: association with
zircon. Structural formula calculated based on $(\mathrm{Ca}+\mathrm{Y}+R E E)=1$ for fluorite and $(\mathrm{Ca}+\mathrm{Y}+R E E)=2$ for synchysite-(Y). The amount of $\mathrm{CO}_{2}$ was calculated by stoichiometry; -: below detection limits. Electronmicroprobe data.

\section{Spessartine}

In the Xihuashan granitic complex, a garnet-group mineral is very rare in the $\mathrm{G}-$ a granite, but is widespread in both the G-b and G-c granites. It occurs as euhedral grains from 100 to $200 \mu \mathrm{m}$ across. Observations in back-scattered electron images indicate that most garnet crystals contain polymineralic inclusions, dominated by Y-bearing minerals, including gadolinite-(Y), xenotime-(Y), fergusonite-(Y), and less commonly, zircon, thorite and uraninite. These inclusions, mostly micrometric, are restricted to the central portion of the crystals (Fig. 3a).

Representative electron-microprobe data (Table 3) define the garnet composition from the Xihuashan as spessartine (spessartine $>50$ mole $\%$ except for a few cases), similar to what is found in rare-metal granitic pegmatites (Černý \& Hawthorne 1982). Analytical data reveal an enrichment in $\mathrm{Y}$ and the heavy REE (HREE), in particular in the core. The maximum concentrations of $\mathrm{Y}_{2} \mathrm{O}_{3}, \mathrm{Gd}_{2} \mathrm{O}_{3}, \mathrm{Er}_{2} \mathrm{O}_{3}, \mathrm{Dy}_{2} \mathrm{O}_{3}$ and $\mathrm{Yb}_{2} \mathrm{O}_{3}$ are 2.32, $0.26,0.35,0.26$ and $0.84 \mathrm{wt} \%$, respectively. Although yttrium and the HREE are particularly compatible with the garnet structure, compositional data for the Y-bearing spessartine, surprisingly, are uncommon and incomplete. Jaffe (1951) demonstrated a correlation between manganese content and yttrium content in garnet. In fact, $\mathrm{Y}$ concentrations in excess of $1 \mathrm{wt} \% \mathrm{Y}_{2} \mathrm{O}_{3}$ are reported to occur in spessartine associated with pegmatitic environments (Jaffe 1951, Wakita et al. 1969). Jaffe (1951) proposed a coupled substitution of the type $\mathrm{Y}^{3+} \mathrm{Al}^{3+} \Leftrightarrow$ $\mathrm{Mn}^{2+} \mathrm{Si}^{4+}$. However, as demonstrated in Figure 4, there is no simple correlation between $\mathrm{Y}+$ HREE and $\mathrm{Mn}$, $\mathrm{Fe}, \mathrm{Ca}$ and $\mathrm{Mg}$ in spessartine in the Xihuashan granites. A negative correlation between $(\mathrm{Y}, R E E)$ and $\mathrm{Al}$ sug- 
TABLE 3. COMPOSITION OF 7ONED SPESSARTINE CRYSIALS FROM TIIE G-c GRANITE AT XIHUASHAN

\begin{tabular}{|c|c|c|c|c|c|c|c|c|c|c|c|c|c|c|}
\hline & Rim & $\stackrel{2}{\text { Core }}$ & $\stackrel{3}{\text { Rim }}$ & $\begin{array}{c}4 \\
\text { Core }\end{array}$ & $\stackrel{5}{\operatorname{Rim}}$ & $\begin{array}{c}6 \\
\text { Core }\end{array}$ & $\begin{array}{c}7 \\
\text { Rim }\end{array}$ & $\stackrel{8}{\text { Rim }}$ & $\begin{array}{c}9 \\
\text { Core }\end{array}$ & $\begin{array}{c}10 \\
\text { Rim }\end{array}$ & $\begin{array}{c}11 \\
\text { Core }\end{array}$ & $\begin{array}{l}12 \\
\text { Rim }\end{array}$ & $\begin{array}{c}13 \\
\text { Core }\end{array}$ & $\begin{array}{c}14 \\
\text { Rim }\end{array}$ \\
\hline $\mathrm{MgO} w \mathrm{t} \%$ & $\%$ & - & - & 0.01 & - & - & - & - & 0.04 & - & - & - & 0.01 & - \\
\hline $\mathrm{Al}_{2} \mathrm{O}_{3}$ & 20.55 & 19.38 & 20.46 & 19.362 & 20.58 & 19.06 & 20.92 & 20.61 & 18.93 & 20.33 & 18.75 & 19.91 & 19.12 & 20.87 \\
\hline $\mathrm{SiO}_{2}$ & 36.21 & 35.43 & 36.01 & 35.09 & 36.33 & 35.23 & 35.92 & 36.22 & 35.06 & 36.33 ? & 34.65 & 35.60 & 35.07 & 36.01 \\
\hline $\mathrm{CaO}$ & 0.76 & 1.37 & 0.62 & 1.37 & 0.77 & 1.46 & 0.62 & 0.66 & 1.76 & 0.66 & 2.22 & 1.14 & 1.54 & 0.63 \\
\hline $\mathrm{Cr}_{2} \mathrm{O}_{3}$ & - & - & - & - & - & 0.01 & - & - & - & & 0.02 & 0.03 & - & 0.03 \\
\hline $\mathrm{MnO}$ & 22.35 & 21.01 & 22.40 & 22.79 & 22.78 & 22.24 & 22.54 & 22.25 & 22.31 & 23.432 & 21.99 & 22.25 & 23.26 & 23.24 \\
\hline $\mathrm{FeO}$ & 20.86 & 20.40 & 20.62 & 17.92 & 19.95 & 18.34 & 20.40 & 21.12 & 17.64 & 20.56 & 18.23 & 19.59 & 17.55 & 19.73 \\
\hline $\mathrm{Y}_{2} \mathrm{O}_{3}$ & 0.29 & 1.58 & 0.18 & 2.14 & 0.12 & 1.99 & 0.05 & 0.06 & 2.32 & 0.06 & 2.17 & 0.91 & 1.71 & 0.21 \\
\hline $\mathrm{Gd}_{2} \mathrm{O}_{3}$ & 0.14 & - & 0.12 & 0.11 & 0.18 & 0.18 & - & - & - & 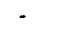 & 0.17 & - & 0.26 & - \\
\hline $\mathrm{Dy}_{2} \mathrm{O}_{3}$ & 0.22 & 0.04 & 0.04 & 0.35 & - & 0.08 & - & 0.09 & 0.13 & 0.04 & - & 0.15 & 0.25 & 0.15 \\
\hline $\mathrm{Er}_{2} \mathrm{O}_{3}$ & 0.03 & 0.13 & 0.09 & 0.26 & - & 0.28 & - & - & 0.19 & - & 0.19 & 0.09 & 0.15 & 0.06 \\
\hline $\mathrm{Yb}_{2} \mathrm{O}_{3}$ & 0.19 & 0.53 & - & 0.79 & 0.03 & 0.54 & 0.10 & 0.18 & 0.84 & 0.10 & 0.48 & 0.13 & 0.39 & 0.20 \\
\hline Total & 101.61 & 99.881 & 100.541 & 100.1710 & 00.74 & 99.411 & 100.551 & 101.19 & 99.211 & 101.49 & 98.87 & 99.81 & 99.311 & 101.14 \\
\hline $\mathrm{Mg}$ apfu & - & - & - & 0.001 & - & - & - & & 0.005 & - & - & - & 0.001 & - \\
\hline $\mathrm{Al}$ & 1.985 & 51.917 & 71.991 & 1.921 & 1.993 & $\begin{array}{ll}3 & 1.899\end{array}$ & 2.030 & 1.993 & 1.892 & 1.963 & 1.883 & 1.958 & 31.907 & 2.020 \\
\hline $\mathrm{Si}$ & 2.967 & 2.973 & 2.973 & 2.953 & 2.985 & $5 \quad 2.977$ & 72.958 & 2.972 & 2.972 & 2.977 & 2.952 & 2.971 & 2.967 & 2.956 \\
\hline $\mathrm{Ca}$ & 0.067 & 0.123 & 0.055 & 0.123 & 0.068 & $\begin{array}{ll}8 & 0.132\end{array}$ & 20.055 & 0.058 & 0.160 & 0.058 & 0.202 & 0.102 & 20.139 & 0.056 \\
\hline $\mathrm{Cr}$ & - & - & - & - & - & 0.001 & $1=$ & - & - & - & 0.002 & 0.002 & $2-$ & 0.002 \\
\hline $\mathrm{Mn}$ & 1.551 & 1.493 & 1.567 & 1.624 & 1.586 & $\begin{array}{ll}6 & 1.592\end{array}$ & 2.572 & 1.546 & 1.602 & 1.626 & 1.587 & 71.573 & 1.667 & 71.616 \\
\hline $\mathrm{Fe}$ & 1.429 & 1.431 & 1.424 & 41.261 & 1.371 & 11.296 & 61.405 & 1.449 & 1.250 & 1.409 & 1.299 & 1.368 & 31.241 & 1.355 \\
\hline $\mathrm{Y}$ & 0.013 & 0.070 & 0.008 & 0.096 & 0.005 & $\begin{array}{ll}5 & 0.089\end{array}$ & 0.002 & 0.003 & 0.104 & 0.003 & 0.099 & 0.040 & 0.077 & 0.009 \\
\hline $\mathrm{Gd}$ & 0.004 & $4-$ & 0.003 & 30.003 & 0.005 & 50.005 & $5-$ & - & - & - & 0.005 & $5-$ & 0.007 & $7-$ \\
\hline Dy & 0.006 & 60.001 & 0.001 & 10.009 & - & 0.002 & $2-$ & 0.002 & 0.003 & 0.001 & - & 0.004 & 40.007 & 0.004 \\
\hline Er & 0.001 & 0.004 & 40.002 & 20.007 & - & 0.007 & $7-$ & & 0.005 & - & 0.005 & 50.002 & 20.004 & 0.002 \\
\hline $\mathrm{Yb}$ & 0.005 & 0.013 & $3-$ & 0.020 & 0.001 & 10.014 & 40.002 & 0.004 & +0.022 & 0.002 & 0.012 & 0.003 & 30.010 & 0.005 \\
\hline Total & 8.028 & 8.025 & 8.024 & 48.018 & 8.014 & 48.014 & 48.024 & +8.027 & 78.015 & 8.039 & 8.046 & 58.023 & 8.027 & 8.025 \\
\hline Sps & 50.90 & 49.00 & 51.43 & 53.97 & 52.43 & 52.71 & 51.85 & 50.65 & 53.09 & 52.58 & 51.40 & 51.70 & 54.67 & 53.40 \\
\hline Alm & 46.90 & 46.96 & 46.75 & 41.91 & 45.34 & 42.91 & 46.34 & 47.46 & 41.44 & 45.55 & 42.05 & 44.94 & 40.72 & 44.76 \\
\hline Pyr & 0.00 & 0.00 & 0.02 & 0.03 & 0.00 & 0.00 & 0.00 & 0.00 & 0.18 & 0.00 & 0.00 & 0.00 & 0.05 & 0.00 \\
\hline Grs & 2.20 & 4.04 & 1.80 & 4.09 & 2.23 & 4.37 & 1.80 & 1.89 & 5.30 & 1.87 & 6.55 & 3.36 & 4.57 & 1.84 \\
\hline
\end{tabular}

Structural formulae are calculated based on $\mathrm{O}=12$ atoms per formula unit (apfu). All Fe is expressed as Fe ${ }^{2+}$. Sps: spessartine; Alm: almandine; Pyr: pyrope; Grs: grossular. -: below detection limits. Electron-microprobe data.

gests an alternative scheme of substitution in the structure, possibly more simply, $(\mathrm{Y}, R E E)^{3+} \Leftrightarrow \mathrm{Al}^{3+}$.

The core of the spessartine is (Y,HREE)-rich and contains $Y$-bearing minerals

Back-scattered electron images generally show a brighter core and a darker rim (Fig. 3a). An inclusionfree, (Y, HREE)-poor rim is clearly indicated by analyses along a line (Fig. 3b). Spot analyses carried out on zoned crystals gives concentrations of $\mathrm{Y}$ and $H R E E$ up to 2.32 and $1.51 \mathrm{wt} \%$ of the respective oxides in the core, but less than 0.3 and $0.6 \mathrm{wt} \%$ at the rim (Table 3 ). In contrast, $\mathrm{Al}$ exhibits a core-to-rim increase, although variability is only at a level of $1-2 \mathrm{wt} \%$, in accordance with a $(\mathrm{Y}, H R E E) \Leftrightarrow \mathrm{Al}$ substitution. Variations in Fe and $\mathrm{Mn}$ are less obvious. Such zoning was documented by several authors, e.g., Hickmott et al. (1987), Lanzirotti (1995), Stowell et al. (1996), and Pyle \& Spear (1999).

The spessartine also contains many micro-inclusions of Y-bearing minerals, such as gadolinite-(Y), fergusonite- $(\mathrm{Y})$ and xenotime- $(\mathrm{Y})$, restricted to the core (Fig. 3a). A combination of Y-mineral inclusions and enrich- ment in $\mathrm{Y}$ in the spessartine core suggests that the early melt that led to the $\mathrm{G}-\mathrm{b}$ and $\mathrm{G}-\mathrm{c}$ units was very enriched in $\mathrm{Y}$.

\section{Gadolinite- $(Y)$}

This mineral is very scarce and found exclusively in form of inclusions in the central part of garnet grains, commonly in association with micrograins of xenotime(Y), fergusonite-(Y) and uraninite, although some discrete grains are also observed. The inclusions of gadolinite-(Y) are irregular in shape, typically 5-20 $\mu \mathrm{m}$ in size, whereas the discrete grains are commonly 0.5 mm across.

\section{Zircon}

Zircon is present in all units of the Xihuashan granites. In the G-a granite, small dipyramids $(\sim 20 \mu \mathrm{m})$ are included randomly in rock-forming minerals (e.g., feldspar, biotite). In the $\mathrm{G}-\mathrm{b}$ and $\mathrm{G}-\mathrm{c}$ granites, zircon occurs mostly as intergranular crystals among quartz, feldspar or biotite. Micro-inclusions are commonly found, but are restricted to the typically inclusion- 

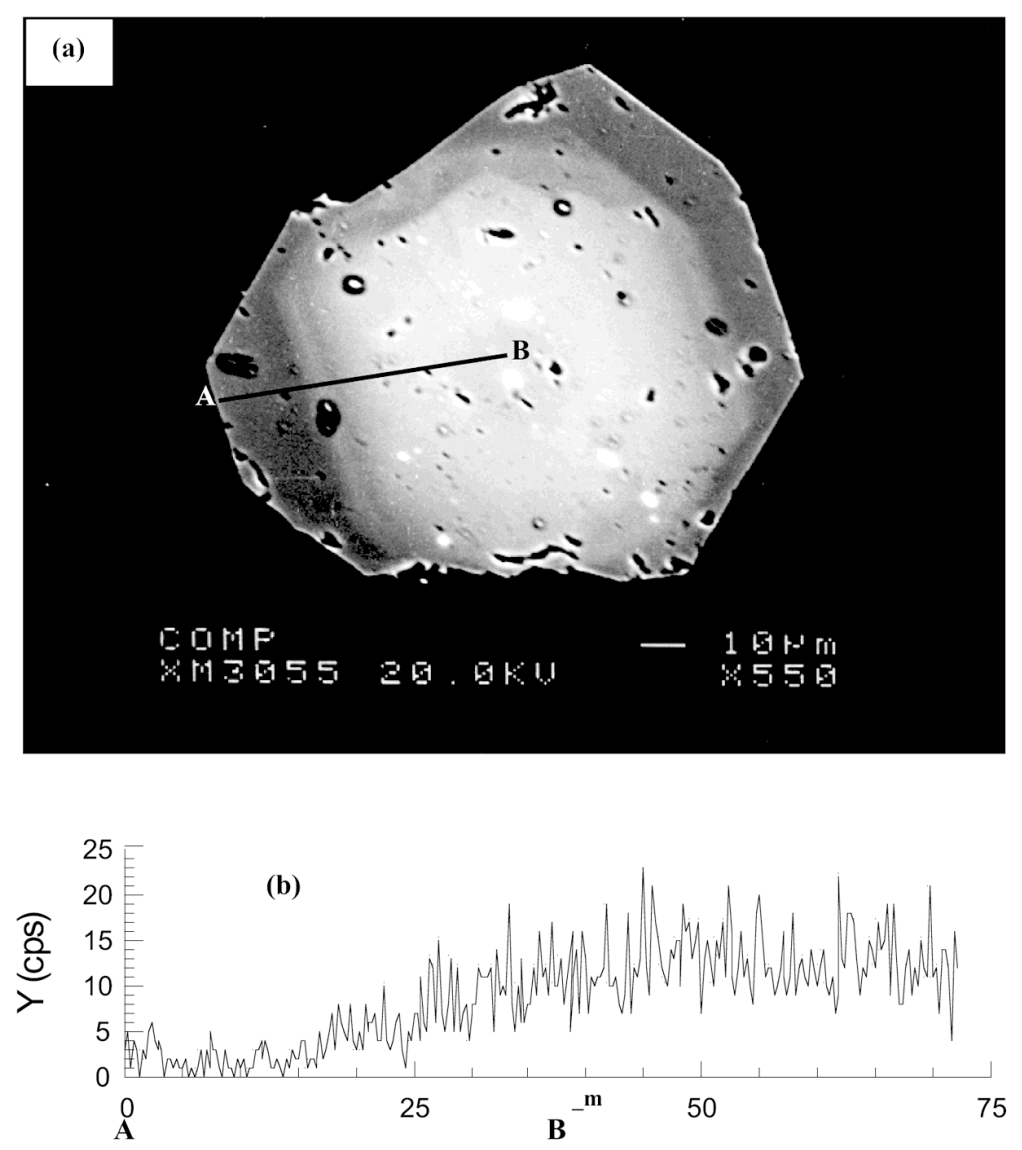

FIG. 3. (a) Back-scattered electron image of zoned grain of spessartine. Small inclusions of gadolinite-(Y) and xenotime-(Y) (bright dots) are restricted to the spessartine core. (b) Line analysis for yttrium along the traverse shown in Figure 3a, illustrating a core enriched in Y relative to the rim.

riddled core, which is mostly enclosed by an outer inclusion-free zone (Figs. 5a, b). Common polymineralic inclusions consist of anhedral xenotime-(Y), thorite and uraninite. Zircon may be also associated with xenotime$(\mathrm{Y})$, thorite and uraninite (Figs. 5b, c). Such aggregates may be observed in association with fluorite II (Fig. 2b). Zircon containing a microcrystal of thorite is included in spessartine (Fig. 5d), and provides information about the sequence of saturation of these minerals in the melt.

We have analyzed forty crystals of zircon. The crystals from the G-a unit are relatively homogeneous (Table 4). The levels of Hf range from 1.66 to $3.68 \mathrm{wt} \%$ $\mathrm{HfO}_{2}$. The proportion of the hafnon end-member $\left(\mathrm{HfSiO}_{4}\right)$, indicated by the atomic ratio $100 \mathrm{Hf} /(\mathrm{Zr}+\mathrm{Hf})$ (Hf\# in Table 4), varies from 1.7 to 3.35, indicating that these crystals are normal zircon according to the termi- nology proposed by Correia Neves et al. (1974). Zircon from the G-b and G-c granites is more enriched in Hf. The levels of $\mathrm{Hf}$ in zircon vary from 1.6 to $20.3 \mathrm{wt} \%$ $\mathrm{HfO}_{2}$ (Nos. 3, 6a, Table 4). The Hf\# is variable, between 1.42 to 19.97 . These crystals are hafnian.

The level of $U$ generally is in the range of 0.08 to $4.81 \mathrm{wt} \% \mathrm{UO}_{2}$, notably lower than contents found in zircon from the Beauvoir granite (up to $10.73 \mathrm{wt} \% \mathrm{UO}_{2}$ : Cuney \& Brouand 1987) or the Yichun granite (up to 9.94 wt $\% \mathrm{UO}_{2}$ : Huang et al. 2002). Thorite incorporates uranium relative to zircon. Where zoned, the rim of the zircon is distinctly poorer in $\mathrm{U}$ than the core. The concentration of Th varies generally in the range from less than the detection limit to $1.89 \mathrm{wt} \% \mathrm{ThO}_{2}$, and that of $\mathrm{Y}$ is from 0.13 to $4.56 \mathrm{wt} \% \mathrm{Y}_{2} \mathrm{O}_{3}$. 

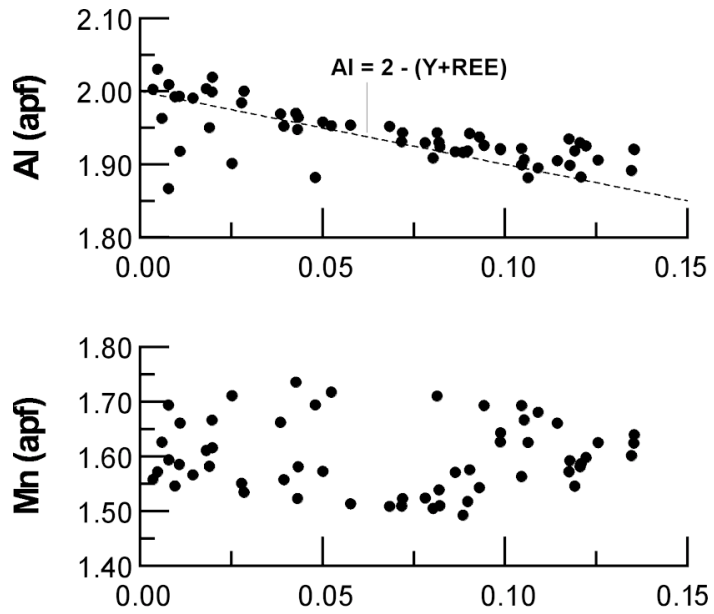

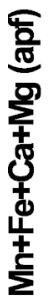

\section{Zonation in zircon}

Zircon generally displays oscillatory zoning, and was studied with BSE images and WDS analyses. As seen in Figure 6, the grains generally exhibit a brighter rim of variable width on BSE images. The map of Hf distribution shows a striking enrichment in Hf at the rim of the crystal. In all cases where multiple analyses could be performed in heterogeneous crystals, guided by BSE images, a systematic core-to-rim increase in Hf was found (Table 4, Fig. 7), in contrast to U, Th and Y, which are depleted at the rim. The phenomenon of outward enrichment in Hf has been described in many granites and granitic pegmatites, e.g., the Beauvoir granite, France (Wang et al. 1992), the Suzhou granite, China (Wang et al. 1996), the Laoshan granite, China (Wang et al. 2000), the Homolka granitic pegmatite, Czech

FIG. 4. Plots of concentrations of $\mathrm{Y}+$ REE versus $\mathrm{Al}, \mathrm{Mn}$ and total of $\mathrm{Mn}, \mathrm{Fe}, \mathrm{Ca}$ and $\mathrm{Mg}$ in the spessartine (in atoms per formula unit).

\begin{tabular}{|c|c|c|c|c|c|c|c|c|c|c|c|c|c|}
\hline & \multicolumn{2}{|c|}{$G-a$} & \multicolumn{9}{|c|}{ G-b } & \multicolumn{2}{|c|}{$\mathrm{G}-\mathrm{c}$} \\
\hline & 1 & 2 & 3 & 4 & 5 & $6 a$ & $6 b$ & $7 a$ & $7 b$ & $8 a$ & $8 \mathrm{c}$ & $9 \mathrm{a}$ & $9 b$ \\
\hline & & & & & & $\mathrm{R}$ & $\mathrm{C}$ & $\mathrm{R}$ & $\mathrm{C}$ & $\mathrm{R}$ & C & $\mathrm{R}$ & $\mathrm{C}$ \\
\hline $\begin{array}{l}\mathrm{SiO}_{2} \mathrm{wt} \% \\
\mathrm{Z} \mathrm{rO}_{2} \\
\mathrm{HFO}_{2} \\
\mathrm{UO}_{2} \\
\mathrm{ThO}_{2} \\
\mathrm{Y}_{2} \mathrm{O}_{3} \\
\mathrm{La}_{2} \mathrm{O}_{3} \\
\mathrm{Ce}_{2} \mathrm{O}_{3} \\
\mathrm{P}_{2} \mathrm{O}_{5} \\
\mathrm{Al}_{2} \mathrm{O}_{3}\end{array}$ & $\begin{array}{c}32.16 \\
63.97 \\
1.91 \\
0.30 \\
0.10 \\
0.47 \\
- \\
0.07 \\
0.23 \\
-\end{array}$ & $\begin{array}{c}32.03 \\
62.13 \\
3.68 \\
0.81 \\
0.01 \\
0.34 \\
- \\
0.02 \\
0.26 \\
-\end{array}$ & $\begin{array}{l}32.23 \\
66.70 \\
1.64 \\
0.18 \\
0.14 \\
0.26 \\
- \\
0.03 \\
0.30 \\
-\end{array}$ & $\begin{array}{l}30.18 \\
56.95 \\
5.28 \\
0.97 \\
0.68 \\
3.10 \\
- \\
0.06 \\
2.10 \\
0.04\end{array}$ & $\begin{array}{r}27.64 \\
51.10 \\
1.55 \\
4.81 \\
1.41 \\
1.51 \\
0.00 \\
0.00 \\
1.18 \\
0.14\end{array}$ & $\begin{array}{r}29.00 \\
47.62 \\
20.29 \\
0.57 \\
0.16 \\
1.14 \\
- \\
0.07 \\
1.08 \\
-\end{array}$ & $\begin{array}{l}31.10 \\
61.58 \\
5.02 \\
0.29 \\
0.03 \\
0.74 \\
0.02 \\
0.02 \\
0.64 \\
-\end{array}$ & $\begin{array}{l}29.06 \\
48.44 \\
19.50 \\
0.45 \\
0.19 \\
1.19 \\
- \\
0.04 \\
0.93 \\
-\end{array}$ & $\begin{array}{r}29.96 \\
55.22 \\
5.06 \\
3.07 \\
0.41 \\
2.36 \\
- \\
0.04 \\
1.06 \\
-\end{array}$ & $\begin{array}{l}30.80 \\
56.37 \\
11.19 \\
0.27 \\
0.02 \\
0.80 \\
- \\
0.03 \\
0.54 \\
-\end{array}$ & $\begin{array}{cc}31.89 & 2 \\
61.69 & 4 \\
4.16 & 1 \\
0.37 \\
- \\
0.67 \\
- \\
0.02 \\
0.48 \\
-\end{array}$ & $\begin{array}{c}29.25 \\
49.64 \\
19.64 \\
0.27 \\
0.09 \\
0.70 \\
- \\
0.03 \\
0.85 \\
0.01\end{array}$ & $\begin{array}{c}30.85 \\
61.75 \\
4.76 \\
0.41 \\
0.11 \\
0.83 \\
- \\
0.03 \\
0.75 \\
-\end{array}$ \\
\hline Total & 99.21 & 99.2910 & 01.489 & 99.36 & 89.34 & 99.93 & 99.44 & 99.80 & 97.181 & 00.02 & 99.2910 & 00.479 & 99.49 \\
\hline $\begin{array}{l}\text { Si apfu } \\
\text { ZI } \\
\text { Hf } \\
\text { U } \\
\text { Th } \\
\text { Y } \\
\mathrm{La} \\
\mathrm{Ce} \\
\mathrm{P} \\
\mathrm{Al}\end{array}$ & $\begin{array}{l}0.998 \\
0.968 \\
0.017 \\
0.002 \\
0.001 \\
0.008 \\
- \\
0.001 \\
0.006 \\
-\end{array}$ & $\begin{array}{l}1.001 \\
0.947 \\
0.033 \\
0.006 \\
0.000 \\
0.006 \\
- \\
0.000 \\
0.007 \\
-\end{array}$ & $\begin{array}{l}0.981 \\
0.990 \\
0.014 \\
0.001 \\
0.001 \\
0.004 \\
- \\
0.000 \\
0.008 \\
-\end{array}$ & $\begin{array}{l}0.953 \\
0.877 \\
0.048 \\
0.007 \\
0.005 \\
0.052 \\
- \\
0.001 \\
0.056 \\
0.002\end{array}$ & $\begin{array}{l}0.981 \\
0.884 \\
0.016 \\
0.038 \\
0.011 \\
0.028 \\
0.000 \\
0.000 \\
0.035 \\
0.006\end{array}$ & $\begin{array}{l}0.970 \\
0.777 \\
0.194 \\
0.004 \\
0.001 \\
0.020 \\
- \\
0.001 \\
0.030 \\
-\end{array}$ & $\begin{array}{l}0.978 \\
0.944 \\
0.045 \\
0.002 \\
0.000 \\
0.012 \\
0.000 \\
0.000 \\
0.017 \\
-\end{array}$ & $\begin{array}{l}0.971 \\
0.789 \\
0.186 \\
0.003 \\
0.001 \\
0.021 \\
- \\
0.000 \\
0.026 \\
-\end{array}$ & $\begin{array}{l}0.979 \\
0.880 \\
0.047 \\
0.022 \\
0.003 \\
0.041 \\
- \\
0.000 \\
0.029 \\
-\end{array}$ & $\begin{array}{l}0.986 \\
0.880 \\
0.102 \\
0.002 \\
0.000 \\
0.014 \\
- \\
0.000 \\
0.015 \\
-\end{array}$ & $\begin{array}{l}0.996 \\
0.940 \\
0.037 \\
0.003 \\
- \\
0.011 \\
- \\
0.000 \\
0.013 \\
-\end{array}$ & $\begin{array}{l}0.970 \\
0.802 \\
0.186 \\
0.002 \\
0.001 \\
0.012 \\
- \\
0.000 \\
0.024 \\
0.000\end{array}$ & $\begin{array}{l}0.970 \\
0.947 \\
0.043 \\
0.003 \\
0.001 \\
0.014 \\
- \\
0.000 \\
0.020 \\
-\end{array}$ \\
\hline Total & 2.001 & 2.000 & 1.999 & 2.001 & 1.999 & 1.997 & 1.998 & 1.997 & 2.001 & 1.999 & 2.000 & 1.997 & 1.998 \\
\hline HHf & 1.7 & 3.4 & 1.4 & 5.2 & 1.7 & 20.0 & 4.6 & 19.1 & 5.1 & 10.4 & 3.8 & 18.8 & 4.3 \\
\hline
\end{tabular}

R: rim. C: core. Structural formulac were calculated based on $\mathrm{O}-4$ atoms per formula unit (apfu). -: below detection limits. $\mathrm{HHf}=100 \times \mathrm{Hf} /(\mathrm{Zr}+\mathrm{Hf})$. Electron-microprobe data. 
Republic (Uher et al. 1998), and likely is a general feature in rare-metal-enriched granites.

On other hand, some grains are marked by a highly U-enriched core (Fig. 8), up to $4.81 \mathrm{wt} \% \mathrm{UO}_{2}$, but also by the presence of numerous micro-inclusions of uraninite. In contrast, the rim contains only $0.79-1.21 \mathrm{wt} \%$ $\mathrm{UO}_{2}$.

In addition, the composition of the core from the G$\mathrm{b}$ and $\mathrm{G}-\mathrm{c}$ units almost overlaps that of zircon from the G-a unit (Fig. 7). In fact, zircon from the G-a contains on average $2.5 \mathrm{wt} \% \mathrm{HfO}_{2}, 0.38 \% \mathrm{UO}_{2}, 0.10 \% \mathrm{ThO}_{2}$ and $0.49 \% \mathrm{Y}_{2} \mathrm{O}_{3}$. Similarly, concentrations of $\mathrm{Hf}, \mathrm{U}, \mathrm{Th}$ and $\mathrm{Y}$ for the zircon core from the $\mathrm{G}-\mathrm{b}$ granite average 3.81, $0.89,0.16$ and $1.13 \mathrm{wt} \%$ of the respective oxides. Overall compositional characteristics suggest that zircon from the G-b and G-c units may be formed initially under conditions similar to those in the $\mathrm{G}-\mathrm{a}$ granite.

\section{Thorite}

Thorite is present in all units of the Xihuashan granitic complex, but differs in its mode of occurrence. It forms inclusions in monazite-(Ce) or xenotime-( $(Y)$ in the $\mathrm{G}-\mathrm{a}$ granite. However, three generations of thorite may be recognized in the G-b and G-c granites: the first generation (thorite I) occurs as micro-inclusions enclosed in zircon commonly in association with xenotime-(Y) (Fig. 5a). Thorite II consists of anhedral grains, generally in contact with zircon in association with xenotime-(Y) or uraninite (or both; Figs. 5b, c). Grains of thorite III are typically small and anhedral, and are associated with apatite and fluorocarbonates of LREE (probably bastnäsite), derived from the alteration of monazite-(Ce) (Fig. 9).

Representative electron-microprobe results (Table 5) show that the $\mathrm{U}$ content is generally more than 11.48
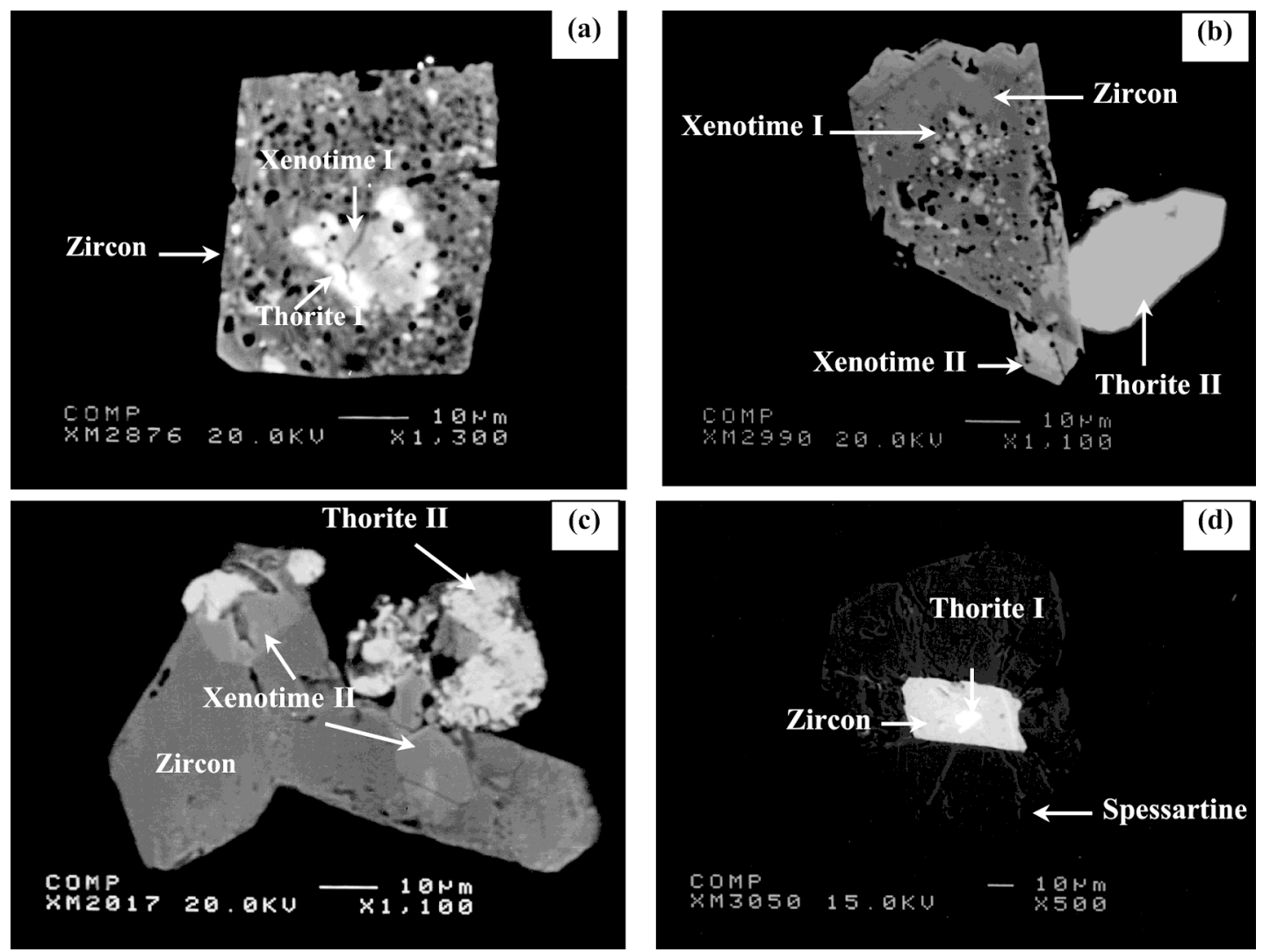

FIG. 5. Back-scattered electron images of zircon and associated minerals. (a) Porous zircon with inclusions of xenotime I and thorite I. (b) Porous zircon with small inclusions of xenotime I. Zircon is outside associated with larger euhedral crystals of xenotime II and thorite II. (c) Association of zircon with xenotime II and thorite II. (d) Zircon with inclusion of thorite I contained within spessartine. 
wt $\% \mathrm{UO}_{2}\left(>13\right.$ mol. $\left.\% \mathrm{USiO}_{4}\right)$, indicating that the thorite is uranoan (Fig. 10). The maximum content of $U$ (32.8 wt $\% \mathrm{UO}_{2}$, No. 12, Table 5) approaches its experimentally established maximum, which is on the order of $33.1 \mathrm{wt} \%$, or $40 \mathrm{~mol}$. $\% \mathrm{USiO}_{4}$ (Zimmer 1986). The inclusions of thorite in zircon commonly incorporate the highest amounts of uranium, whereas the lowest contents of $\mathrm{U}\left(<17 \mathrm{wt} \% \mathrm{UO}_{2}\right)$ typify the discrete grains (e.g., Nos. 4, 9, Table 5).

Thorite contains also Y, but generally below $5 \mathrm{wt} \%$ $\mathrm{Y}_{2} \mathrm{O}_{3}$. Contents as high as $16 \mathrm{wt} \% \mathrm{Y}_{2} \mathrm{O}_{3}$ invariably pertain to small grains coexisting with xenotime-(Y), and may well be due to overlap problems owing to grain size.

Thorite derived from the alteration of monazite is compositionally characterized by $24.5-26.5 \mathrm{wt} \% \mathrm{ThO}_{2}$ and $1-4 \mathrm{wt} \% \quad \mathrm{Y}_{2} \mathrm{O}_{3}$, and exhibits extensive metamictization, as demonstrated by low analytical totals $(<93$ wt $\%$ ), probably due to the presence of $\mathrm{H}_{2} \mathrm{O}$.

\section{Xenotime- $(Y)$}

Xenotime-(Y) is particularly abundant in Ca-poor peraluminous granites accounting for a large fraction of the $\mathrm{Y}$ and heavy REE (HREE) contents in the whole rocks (Wark \& Miller 1993, Bea 1996, Förster 1998b).

Xenotime-(Y) is observed throughout the Xihuashan complex, and represents the most important carrier of yttrium. In the G-a unit, it occurs as the only mineral of yttrium, in association with monazite-(Ce) containing thorite inclusions. Two generations are distinguished in the $\mathrm{G}-\mathrm{b}$ and $\mathrm{G}-\mathrm{c}$ granites. Xenotime I consists of micro-inclusions enclosed in the core of zircon, commonly accompanied by anhedral thorite, suggesting a primary mineral having the composition $(\mathrm{Zr}, \mathrm{Th}, \mathrm{Y})(\mathrm{Si}, \mathrm{P}) \mathrm{O}_{4}$ (Figs. 5a, b). Anhedral crystals also are observed as micro-inclusions in the Y-rich core of garnet crystals. Xenotime II forms larger euhedral crystals, and generally surrounds zircon (Figs. 5b, c).
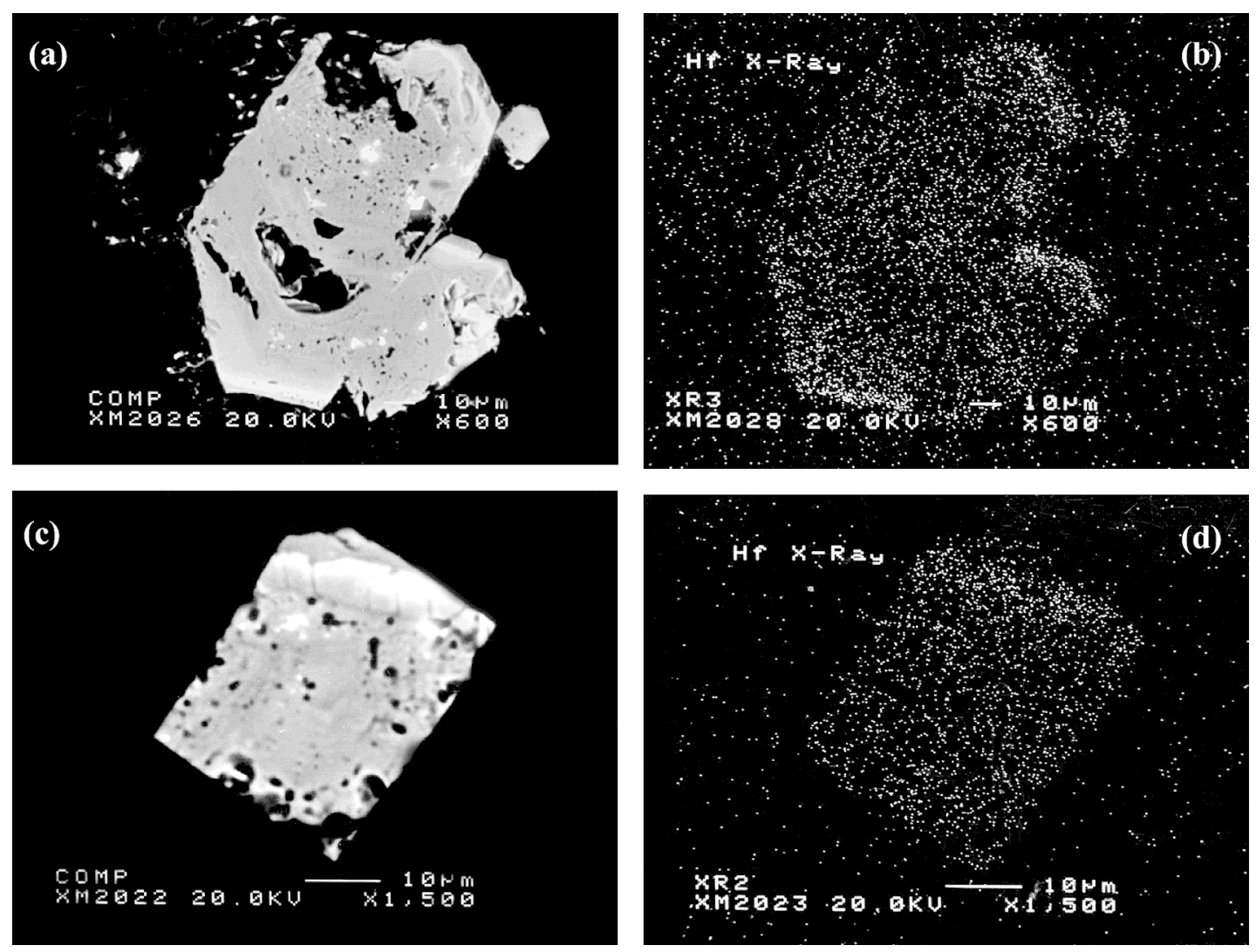

FIG. 6. Back-scattered electron images of zoned zircon $(\mathrm{a}, \mathrm{c})$. Images of distribution of $\mathrm{Hf}(\mathrm{b}, \mathrm{d})$ reveal a pattern of Hf enrichment toward the margin. 
TABLE 5. REPRESENTATIVE COMPOSITIONS OF THORITE FROM THE XIIUUASHAN GRANITIC COMPLEX, CHINA

\begin{tabular}{|c|c|c|c|c|c|c|c|c|c|c|c|c|c|c|c|c|c|c|}
\hline & \multirow{2}{*}{$\frac{\mathrm{G}-\mathrm{a}}{\mathrm{1}}$} & \multicolumn{16}{|c|}{$\mathrm{G}-\mathrm{b}$} & \multirow{2}{*}{$\begin{array}{c}\text { G-c } \\
18 \\
\text { IZ }\end{array}$} \\
\hline & & $\begin{array}{l}2 \\
\mathrm{D}\end{array}$ & $\begin{array}{l}3 \\
\mathrm{D}\end{array}$ & $\begin{array}{l}4 \\
\mathrm{D}\end{array}$ & $\stackrel{5}{W Z}$ & $\begin{array}{c}6 \\
\mathrm{IZ}\end{array}$ & $\begin{array}{c}7 \\
\mathrm{IZ}\end{array}$ & $\begin{array}{c}8 \\
\text { WZ }\end{array}$ & $\begin{array}{l}9 \\
\mathrm{D}\end{array}$ & $\begin{array}{l}10 \\
D\end{array}$ & $\begin{array}{l}11 \\
1 Z\end{array}$ & $\begin{array}{l}12 \\
\mathrm{IZ}\end{array}$ & $\begin{array}{l}13 \\
\text { IZ }\end{array}$ & $\begin{array}{l}14 \\
\text { Sec }\end{array}$ & $\begin{array}{l}15 \\
\text { Sec }\end{array}$ & $\begin{array}{l}16 \\
\text { Sec }\end{array}$ & $\begin{array}{l}17 \\
\text { Sec }\end{array}$ & \\
\hline $\begin{array}{l}\mathrm{SiO}_{2} \mathrm{wt} \% \\
\mathrm{UO}_{2} \\
\mathrm{ThO}_{2} \\
\mathrm{P}_{2} \mathrm{O}_{5} \\
\mathrm{Y}_{2} \mathrm{O}_{3} \\
\mathrm{PbO} \\
\mathrm{La}_{2} \mathrm{O}_{3} \\
\mathrm{Ce}_{2} \mathrm{O}_{3} \\
\mathrm{CaO}\end{array}$ & $\begin{array}{l}16.53 \\
25.00 \\
49.88 \\
1.89 \\
3.10 \\
1.08 \\
- \\
- \\
0.17\end{array}$ & $\begin{array}{l}14.38 \\
15.59 \\
61.68 \\
1.49 \\
2.90 \\
0.21 \\
- \\
- \\
0.38\end{array}$ & $\begin{array}{c}14.82 \\
16.69 \\
55.06 \\
2.72 \\
4.17 \\
0.28 \\
- \\
0.24 \\
0.36\end{array}$ & $\begin{array}{r}14.82 \\
15.05 \\
61.38 \\
1.35 \\
2.82 \\
0.16 \\
0.02 \\
0.19 \\
0.37\end{array}$ & $\begin{array}{c}14.41 \\
25.01 \\
51.78 \\
2.98 \\
4.41 \\
0.20 \\
- \\
0.09 \\
0.31\end{array}$ & $\begin{array}{c}16.56 \\
27.55 \\
50.61 \\
1.71 \\
2.19 \\
1.10 \\
- \\
0.04 \\
-\end{array}$ & $\begin{array}{c}17.41 \\
29.91 \\
48.44 \\
1.19 \\
1.59 \\
1.10 \\
- \\
0.03 \\
0.07\end{array}$ & $\begin{array}{r}15.64 \\
15.28 \\
58.27 \\
1.29 \\
3.76 \\
0.18 \\
0.08 \\
0.24 \\
0.39\end{array}$ & $\begin{array}{r}15.90 \\
11.48 \\
60.68 \\
1.42 \\
2.62 \\
0.22 \\
0.06 \\
0.01 \\
0.59\end{array}$ & $\begin{array}{c}15.50 \\
15.27 \\
53.35 \\
2.11 \\
5.30 \\
0.17 \\
- \\
0.01 \\
0.40\end{array}$ & $\begin{array}{r}16.82 \\
26.30 \\
48.18 \\
2.32 \\
3.54 \\
0.33 \\
0.03 \\
- \\
0.78\end{array}$ & $\begin{array}{c}16.02 \\
32.83 \\
45.45 \\
1.46 \\
1.79 \\
1.08 \\
- \\
- \\
0.56\end{array}$ & $\begin{array}{r}14.97 \\
30.96 \\
43.23 \\
3.32 \\
4.03 \\
0.80 \\
0.06 \\
0.04 \\
0.45\end{array}$ & $\begin{array}{c}16.52 \\
26.22 \\
47.09 \\
1.28 \\
1.02 \\
0.13 \\
- \\
0.04 \\
0.24\end{array}$ & $\begin{array}{r}16.64 \\
26.47 \\
46.13 \\
1.37 \\
1.29 \\
0.21 \\
0.01 \\
- \\
0.25\end{array}$ & $\begin{array}{r}18.22 \\
24.49 \\
45.14 \\
0.25 \\
1.84 \\
0.14 \\
- \\
0.04 \\
0.15\end{array}$ & $\begin{array}{c}16.72 \\
25.58 \\
46.98 \\
1.18 \\
1.02 \\
0.18 \\
- \\
- \\
0.23\end{array}$ & $\begin{array}{r}15.48 \\
22.58 \\
49.74 \\
0.93 \\
1.03 \\
0.30 \\
- \\
0.03 \\
2.09\end{array}$ \\
\hline Total & 97.65 & 96.63 & 94.33 & 96.16 & 99.19 & 99.75 & 99.73 & 95.13 & 92.97 & $92.11 \mathrm{~g}$ & 98.28 & 99.19 & 97.85 & 92.53 & 92.36 & 90.28 & 91.90 & 92.18 \\
\hline $\begin{array}{l}\text { Si apfu } \\
\text { U } \\
\text { Th } \\
\mathrm{P} \\
\mathrm{Y} \\
\mathrm{Pb} \\
\mathrm{La} \\
\mathrm{Ce} \\
\mathrm{Ca} \\
\text { Total }\end{array}$ & $\begin{array}{l}0.903 \\
0.304 \\
0.620 \\
0.087 \\
0.090 \\
0.016 \\
- \\
- \\
0.010 \\
2.030\end{array}$ & $\begin{array}{l}0.833 \\
0.201 \\
0.812 \\
0.073 \\
0.089 \\
0.003 \\
- \\
- \\
0.024 \\
2.035\end{array}$ & $\begin{array}{l}0.833 \\
0.209 \\
0.703 \\
0.129 \\
0.125 \\
0.004 \\
- \\
0.005 \\
0.021 \\
2.029\end{array}$ & $\begin{array}{l}0.855 \\
0.193 \\
0.805 \\
0.066 \\
0.087 \\
0.002 \\
0.001 \\
0.004 \\
0.023 \\
2.036\end{array}$ & $\begin{array}{l}0.787 \\
0.304 \\
0.643 \\
0.138 \\
0.128 \\
0.003 \\
- \\
0.002 \\
0.018 \\
2.023\end{array}$ & $\begin{array}{l}0.899 \\
0.333 \\
0.624 \\
0.079 \\
0.063 \\
0.016 \\
- \\
0.001 \\
- \\
2.015\end{array}$ & $\begin{array}{l}0.943 \\
0.361 \\
0.597 \\
0.054 \\
0.046 \\
0.016 \\
- \\
0.001 \\
0.004 \\
2.022\end{array}$ & $\begin{array}{l}0.889 \\
0.193 \\
0.753 \\
0.062 \\
0.114 \\
0.003 \\
0.002 \\
0.005 \\
0.023 \\
2.044\end{array}$ & $\begin{array}{l}0.916 \\
0.147 \\
0.795 \\
0.069 \\
0.080 \\
0.003 \\
0.001 \\
0.000 \\
0.036 \\
2.047\end{array}$ & $\begin{array}{l}0.878 \\
0.192 \\
0.687 \\
0.101 \\
0.160 \\
0.003 \\
- \\
0.000 \\
0.024 \\
2.045\end{array}$ & $\begin{array}{l}0.901 \\
0.314 \\
0.587 \\
0.105 \\
0.101 \\
0.005 \\
0.000 \\
- \\
0.045 \\
2.058\end{array}$ & $\begin{array}{l}0.896 \\
0.409 \\
0.578 \\
0.069 \\
0.053 \\
0.016 \\
- \\
- \\
0.034 \\
2.055\end{array}$ & $\begin{array}{l}0.815 \\
0.375 \\
0.535 \\
0.153 \\
0.117 \\
0.012 \\
0.001 \\
0.001 \\
0.026 \\
2.035\end{array}$ & $\begin{array}{l}0.949 \\
0.335 \\
0.616 \\
0.062 \\
0.031 \\
0.002 \\
- \\
0.001 \\
0.015 \\
2.011\end{array}$ & $\begin{array}{ll}9 & 0.953 \\
5 & 0.337 \\
6 & 0.600 \\
2 & 0.066 \\
1 & 0.039 \\
2 & 0.003 \\
& 0.000 \\
1 & - \\
5 & 0.015 \\
1 & 2.013\end{array}$ & $\begin{array}{l}1.043 \\
0.312 \\
0.588 \\
0.012 \\
0.056 \\
0.002 \\
- \\
0.001 \\
0.009 \\
2.023\end{array}$ & $\begin{array}{ll} & 0.963 \\
0 & 0.328 \\
0.615 \\
0.057 \\
0.031 \\
0.003 \\
- \\
- \\
0.014 \\
2.011\end{array}$ & $\begin{array}{l}0.942 \\
0.306 \\
0.688 \\
0.048 \\
0.033 \\
0.005 \\
- \\
0.001 \\
0.136 \\
2.159\end{array}$ \\
\hline $\begin{array}{l}\mathrm{USiO}_{4} \\
\mathrm{ThSiO}_{4} \\
\mathrm{YPO}_{4}\end{array}$ & $\begin{array}{r}31.06 \\
60.18 \\
8.76\end{array}$ & $\begin{array}{r}18.46 \\
73.44 \\
8.10\end{array}$ & $\begin{array}{l}20.36 \\
67.27 \\
12.37\end{array}$ & $\begin{array}{r}17.92 \\
73.73 \\
8.35\end{array}$ & $\begin{array}{l}28.42 \\
59.53 \\
12.05\end{array}$ & $\begin{array}{c}33.63 \\
60.21 \\
6.16\end{array}$ & $\begin{array}{r}36.94 \\
58.51 \\
4.55\end{array}$ & $\begin{array}{l}18.33 \\
70.40 \\
11.27\end{array}$ & $\begin{array}{r}14.65 \\
77.38 \\
7.97\end{array}$ & $\begin{array}{l}18.73 \\
65.93 \\
15.35\end{array}$ & $\begin{array}{l}31.63 \\
58.31 \\
10.06\end{array}$ & $\begin{array}{c}40.23 \\
54.72 \\
5.05\end{array}$ & $\begin{array}{l}37.16 \\
51.42 \\
11.42\end{array}$ & $\begin{array}{r}34.26 \\
62.49 \\
3.24\end{array}$ & $\begin{array}{r}34.73 \\
61.25 \\
4.03\end{array}$ & $\begin{array}{r}32.77 \\
61.29 \\
5.94\end{array}$ & $\begin{array}{r}33.84 \\
62.95 \\
3.21\end{array}$ & $\begin{array}{r}30.08 \\
66.61 \\
3.31\end{array}$ \\
\hline
\end{tabular}

Structural formula calculated on the basis of $\mathrm{O}=4$ atoms per formula unit ( $a p f u$ ). - below detection limits. IZ: inclusion in zircon; D: discrete grain, WZ: associated with zircon, Sec: Secondary crystal. Electron-microprobe data.

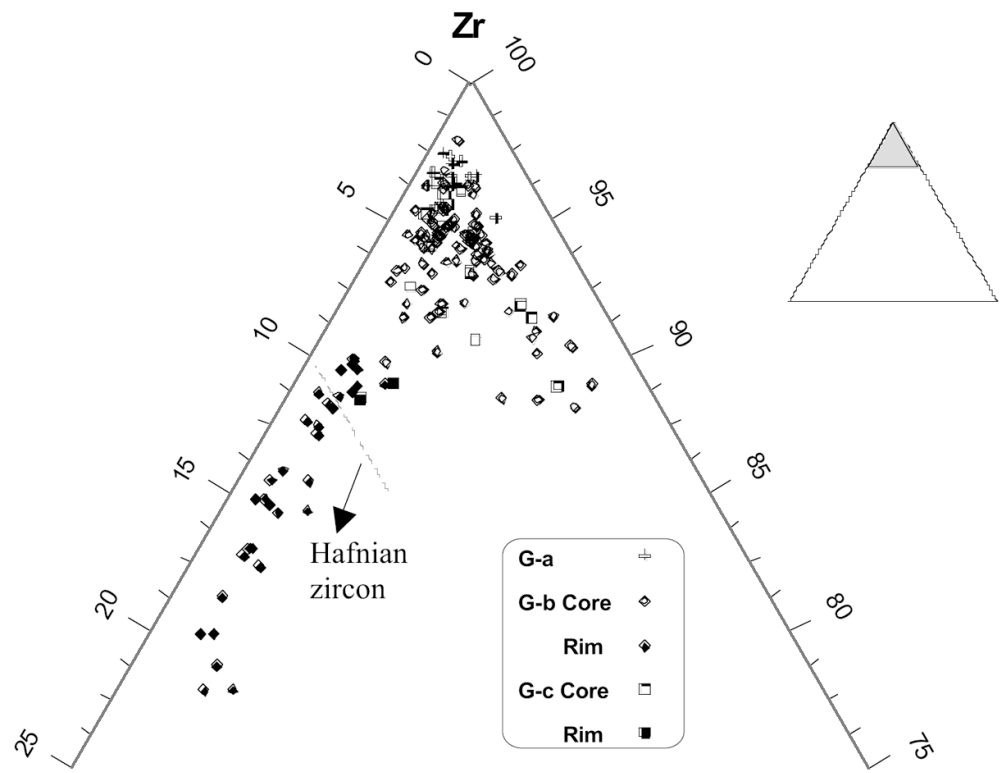

Hf

$\mathrm{U}+\mathrm{Th}+\mathrm{Y}$.

FIG. 7. Plot of compositions of zircon in the triangular diagram $\mathrm{Zr}-\mathrm{Hf}-(\mathrm{U}+\mathrm{Th}+\mathrm{Y}+$ $R E E)$ (atom \%). 
An accurate composition of the micro-inclusions of xenotime-(Y) could not be determined owing to their very small dimension (generally less than $2 \mu \mathrm{m}$ in diameter). Representative electron-microprobe results on xenotime II are shown in Table 6. The LREE oxide concentrations are mostly below $1 \mathrm{wt} \%$; however, the HREE concentrations are variable, ranging from 8.4 to $25.18 \mathrm{wt} \%$ of the respective oxides. Both of the actinide elements, $\mathrm{U}$ and $\mathrm{Th}$, are present in concentrations less than $1 \mathrm{wt} \% \mathrm{UO}_{2}$ or $\mathrm{ThO}_{2}$, although one analysis did give a maximum $\mathrm{Th}$ content of $2.04 \mathrm{wt} \% \mathrm{ThO}_{2}$ (no. 7 , Table 6), and several spots gave $U$ contents of 1-1.5 $\mathrm{wt} \% \mathrm{UO}_{2} . \mathrm{CaO}$ concentrations are mostly less than 1 $\mathrm{wt} \% \mathrm{CaO}$.

\section{Monazite-(Ce)}

Monazite-(Ce) is the typical carrier of the light rareearth elements (LREE) in S-type granites (Broska et al. 2000), and in the Xihuashan complex. It is restricted to

\begin{tabular}{|c|c|c|c|c|c|c|c|c|c|c|}
\hline & \multicolumn{7}{|c|}{ G-b } & \multicolumn{3}{|c|}{ G-c } \\
\hline & 1 & 2 & 3 & 4 & 5 & 6 & 7 & 8 & 9 & 10 \\
\hline $\mathrm{P}, \mathrm{O}_{5} \mathrm{wt} \%$ & 34.3 & 33.75 & 34.87 & 34.45 & 33.68 & 35.42 & 33.17 & 34.62 & 34.87 & 35.06 \\
\hline $\mathrm{SiO}_{2}$ & - & - & - & - & 0.45 & - & 0.29 & 0.51 & 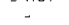 & 0.02 \\
\hline $\mathrm{ThO}_{2}$ & 0.08 & 0.39 & - & 0.14 & 0.69 & 0.04 & 2.04 & 0.15 & - & 0.47 \\
\hline $\mathrm{UO}_{2}$ & 0.68 & 0.48 & - & 0.87 & 1.10 & 0.22 & 2.57 & 0.68 & - & 0.4 \\
\hline $\mathrm{Y}_{2} \mathrm{O}_{3}$ & 40.35 & 39.39 & 40.46 & 41.44 & 41.04 & 46.06 & 33.67 & 44.59 & 40.46 & 43.29 \\
\hline $\mathrm{Lan}_{3}$ & 0.13 & - & 0.32 & 0.09 & - & 0.02 & - & 0.08 & 0.32 & - \\
\hline $\mathrm{Ce}_{2} \mathrm{O}_{3}$ & 0.11 & 0.11 & 0.58 & 0.07 & 0.15 & 0.20 & 0.03 & 0.01 & 0.58 & 0.08 \\
\hline $\mathrm{Nd}_{2} \mathrm{O}_{3}$ & 0.66 & 0.48 & - & 0.17 & - & - & 0.31 & - & - & 0.28 \\
\hline $\mathrm{Sm}_{2} \mathrm{O}_{3}^{3}$ & 0.91 & 0.79 & 0.06 & 1.09 & 0.52 & 0.47 & 0.95 & - & 0.06 & 0.35 \\
\hline $\mathrm{Gd}_{2} \mathrm{O}_{3}$ & 5.60 & 5.43 & 4.5 & 4.645 & 4.63 & 2.24 & 3.00 & 0.91 & 4.41 & 4.01 \\
\hline $\mathrm{Tb}_{2} \mathrm{O}_{3}$ & 0.74 & 0.69 & 0.74 & 0.66 & 0.59 & 0.47 & 1.13 & 0.29 & 0.74 & 0.58 \\
\hline $\mathrm{Dy}, \mathrm{O}_{3}$ & 6.95 & 7.15 & 6.25 & 5.61 & 5.52 & 3.56 & 6.60 & 2.74 & 5.625 & $\begin{array}{ll}5 \quad 4.70 \\
\text { S }\end{array}$ \\
\hline $\mathrm{Ho}_{2} \mathrm{O}_{3}$ & 1.37 & 0.96 & 0.69 & 0.61 & 1.17 & 1.01 & 1.05 & 0.75 & 0.69 & - \\
\hline $\mathrm{Hr}_{2} \mathrm{O}_{3}$ & 4.43 & 5.18 & 5.09 & 3.85 & 4.24 & 3.92 & 6.38 & 4.25 & 5.09 & 4.87 \\
\hline $\mathrm{Tm}_{2} \mathrm{O}_{3}$ & 0.44 & 0.44 & 0.45 & 0.53 & 0.40 & 0.81 & 0.34 & 0.84 & 0.45 & 0.64 \\
\hline $\mathrm{Yb}_{2} \mathrm{O}_{3}^{3}$ & 3.43 & 4.15 & 4.44 & 4.35 & 3.97 & 4.90 & 6.32 & 6.03 & 4.44 & 4.17 \\
\hline $\mathrm{Lu}_{2} \mathrm{O}_{3}$ & 0.2 & 0.91 & 0.08 & 0.35 & - & 0.16 & 0.35 & 0.08 & 0.08 & 0.48 \\
\hline $\mathrm{CaO}$ & - & 0.06 & 0.01 & - & 0.01 & 0.06 & 0.05 & 0.07 & 0.01 & 0.04 \\
\hline $\mathrm{PbO}$ & 0.35 & 0.32 & 0.46 & 0.32 & 0.67 & 0.30 & 0.46 & 1.81 & 0.46 & 0.38 \\
\hline Total & 100.73 & 00.68 & 99.00 & 99.25 & 98.83 & 99.86 & 98.73 & 98.41 & 98.29 & 99.82 \\
\hline $\mathrm{P}$ apfu & 1.000 & 1.000 & 1.000 & $\begin{array}{ll}0 & 1.000\end{array}$ & 0.984 & 1.000 & $0 \quad 0.990$ & 0.983 & 31.000 & $0 \quad 0.999$ \\
\hline $\mathrm{Si}$ & - & - & - & - & 0.016 & $6-$ & 0.010 & 0.017 & $7-$ & 0.001 \\
\hline Th & 0.001 & 0.003 & $3-$ & 0.001 & 0.005 & 0.000 & $0 \quad 0.016$ & 60.001 & - & 0.004 \\
\hline U & 0.005 & 0.004 & +- & 0.007 & 0.008 & 0.002 & 20.020 & 0.005 & $5-$ & 0.003 \\
\hline Y & 0.739 & 0.734 & 10.729 & 90.756 & 0.754 & 0.817 & 70.631 & 0.796 & $\begin{array}{ll}6 & 0.729\end{array}$ & $\begin{array}{ll}9 & 0.776\end{array}$ \\
\hline $\mathrm{La}$ & 0.002 & $2-$ & 0.004 & 40.001 & - & 0.000 & 0 - & 0.000 & $0 \quad 0.002$ & $2-$ \\
\hline $\mathrm{Ce}$ & 0.001 & 0.001 & 0.007 & 70.001 & 0.002 & 0.002 & 20.000 & 0.000 & 00.007 & 70.001 \\
\hline Nd & 0.008 & 0.006 & $5-$ & 0.002 & - & - & 0.004 & $4-$ & - & 0.003 \\
\hline $\mathrm{Sm}$ & 0.011 & 0.010 & 0.001 & 10.013 & 0.006 & 0.005 & $5 \quad 0.012$ & $2-$ & 0.001 & 10.004 \\
\hline $\mathrm{Gd}$ & 0.064 & 0.063 & 0.051 & 10.053 & 0.053 & 0.025 & 50.035 & 50.010 & $\begin{array}{ll}0 & 0.049\end{array}$ & 90.045 \\
\hline $\mathrm{Tb}$ & 0.008 & 0.008 & 0.008 & $\begin{array}{ll}8 & 0.007\end{array}$ & 0.007 & 0.005 & 50.013 & 0.003 & 30.008 & 80.006 \\
\hline Dy & 0.077 & 0.081 & 0.068 & $\begin{array}{ll}8 & 0.062\end{array}$ & 0.061 & 0.038 & 80.075 & 0.030 & $\begin{array}{lll}0 & 0.061\end{array}$ & 10.051 \\
\hline Ho & 0.015 & 0.011 & 0.007 & 70.007 & 0.013 & 0.011 & 10.012 & 20.008 & $\begin{array}{ll}8 & 0.007\end{array}$ & $7-$ \\
\hline $\mathrm{Er}$ & 0.048 & 0.057 & 0.054 & $\begin{array}{lll}4 & 0.041\end{array}$ & 0.046 & 0.041 & 10.071 & 0.045 & $\begin{array}{lll}5 & 0.054\end{array}$ & 40.051 \\
\hline $\mathrm{Tm}$ & 0.000 & 0.000 & 0.000 & $0 \quad 0.006$ & 0.004 & 0.008 & 80.000 & 0.009 & 90.005 & 50.007 \\
\hline $\mathrm{Yb}$ & 0.036 & 0.044 & 0.046 & $\begin{array}{l}60.045 \\
\end{array}$ & 0.042 & 0.050 & 00.068 & 30.062 & 20.046 & 60.043 \\
\hline $\mathrm{Lu}$ & 0.000 & 0.000 & 0.000 & $0 \quad 0.004$ & - & 0.002 & 20.000 & 0.001 & 10.001 & 10.005 \\
\hline $\mathrm{Ca}$ & & 0.002 & 0.000 & $0-$ & 0.000 & 0.002 & 20.002 & 0.003 & $\begin{array}{ll}30.000 \\
\end{array}$ & 00.001 \\
\hline $\mathrm{Pb}$ & 0.003 & 0.003 & 0.004 & 40.003 & 0.006 & 0.003 & 30.004 & 40.016 & $\begin{array}{ll}6 & 0.004\end{array}$ & 40.003 \\
\hline Total & 1.018 & 1.027 & 0.979 & $9 \quad 1.009$ & 1.007 & 1.011 & 10.963 & 0.989 & $\begin{array}{ll}9 & 0.974\end{array}$ & 41.003 \\
\hline
\end{tabular}

Structural formula calculated based on $\mathrm{P}+\mathrm{Si}=1$ atom per formula unit $(a p f u)$. $-:$ below detection limits. Electron-microprobe data. the early stage of granite crystallization (the G-a granite), where it may form aggregates with xenotime-(Y) [much less abundant than monazite-(Ce)], zircon and thorite. In the G-b granite, monazite-(Ce) is only sporadically observed, with secondary thorite + bastnäsite(Ce) + fluorapatite in aggregates (Fig. 9). Compositions of monazite-(Ce) are characterized by $0.65-2.06 \mathrm{wt} \%$ $\mathrm{SiO}_{2}, 4.06-10.73 \% \mathrm{ThO}_{2}, 0.2-0.43 \% \mathrm{UO}_{2}, 0.69-1.74 \%$ $\mathrm{Y}_{2} \mathrm{O}_{3}$ and $0.12-0.83 \% \mathrm{CaO}$ (Table 7). Monazite from S-type granites generally contains $6-12 \mathrm{wt} \% \mathrm{ThO}_{2}$ (Cuney \& Friedrich 1987) or 4-12 wt\% $\mathrm{ThO}_{2}$ (Förster 1998a). In fact, concentrations of Th in monazite-(Ce) from the G-a granite fall near or within this range. The positive relationship between $\mathrm{Th}$ and $\mathrm{Si}$ indicates the existence of the huttonite component in solid solution up to $10 \mathrm{~mol}$. \% (No. 4, Table 7).

\section{Synchysite- $(Y)$}

This mineral is found only as bladed elongate crystals in an assemblage with fluorite III, in which it is dis-

TABLE 7. REPRESENTATIVE COMPOSITIONS OI MONAZITE-(Cc) FROM THE G-a GRANITF AT XIHUASHAN, CHINA

\begin{tabular}{|c|c|c|c|c|c|c|}
\hline & 1 & 2 & 3 & 4 & 5 & 6 \\
\hline $\begin{array}{l}\mathrm{P}_{2} \mathrm{O}_{5} \mathrm{wt}^{\circ} \\
\mathrm{SiO}_{2} \\
\mathrm{ThO}_{2} \\
\mathrm{UO}_{2} \\
\mathrm{Y}_{2} \mathrm{O}_{3} \\
\mathrm{Za}_{2} \mathrm{O}_{3} \\
\mathrm{Ce}_{2} \mathrm{O}_{3} \\
\mathrm{Pr}_{2} \mathrm{O}_{3} \\
\mathrm{Nd}_{2} \mathrm{O}_{3} \\
\mathrm{Sm}_{2} \mathrm{O}_{3} \\
\mathrm{Gd}_{2} \mathrm{O}_{3} \\
\mathrm{~Tb}_{2} \mathrm{O}_{3} \\
\mathrm{Dy}_{2} \mathrm{O}_{3} \\
\mathrm{Ho}_{2} \mathrm{O}_{3} \\
\mathrm{Er}_{2} \mathrm{O}_{3} \\
\mathrm{Tm}_{2} \mathrm{O}_{3} \\
\mathrm{Yb}_{2} \mathrm{O}_{3} \\
\mathrm{Lu}_{2} \mathrm{O}_{3} \\
\mathrm{CaO}_{3} \\
\mathrm{PbO}\end{array}$ & $\begin{array}{r}30.55 \\
0.65 \\
4.06 \\
0.26 \\
0.95 \\
13.26 \\
28.83 \\
0.78 \\
12.85 \\
2.82 \\
2.12 \\
0.12 \\
0.54 \\
0.28 \\
0.15 \\
0.32 \\
0.11 \\
0.01 \\
0.24 \\
0.08\end{array}$ & $\begin{array}{r}29.23 \\
1.03 \\
6.95 \\
0.43 \\
0.98 \\
12.79 \\
25.30 \\
0.65 \\
11.99 \\
3.06 \\
2.26 \\
0.00 \\
0.63 \\
0.00 \\
0.07 \\
0.04 \\
0.04 \\
- \\
0.32 \\
-\end{array}$ & $\begin{array}{r}28.33 \\
1.40 \\
7.87 \\
0.31 \\
0.80 \\
14.53 \\
28.18 \\
0.58 \\
10.68 \\
2.23 \\
1.76 \\
0.01 \\
0.50 \\
0.07 \\
0.01 \\
0.12 \\
0.21 \\
0.02 \\
0.31 \\
0.11\end{array}$ & $\begin{array}{r}26.83 \\
2.06 \\
10.73 \\
0.40 \\
0.99 \\
9.97 \\
23.06 \\
- \\
14.20 \\
4.72 \\
2.34 \\
0.09 \\
0.84 \\
- \\
0.13 \\
0.21 \\
0.68 \\
- \\
0.16 \\
0.10\end{array}$ & $\begin{array}{r}28.11 \\
1.73 \\
6.87 \\
0.20 \\
1.74 \\
12.35 \\
27.15 \\
- \\
12.68 \\
2.51 \\
1.43 \\
0.02 \\
0.69 \\
0.11 \\
0.30 \\
0.04 \\
0.02 \\
- \\
0.12 \\
0.04\end{array}$ & $\begin{array}{r}28.53 \\
0.74 \\
6.57 \\
0.30 \\
0.69 \\
12.22 \\
25.31 \\
- \\
11.70 \\
4.78 \\
2.69 \\
0.19 \\
0.74 \\
- \\
- \\
0.40 \\
- \\
- \\
0.83 \\
-\end{array}$ \\
\hline Total & 98.98 & 95.77 & 98.02 & 97.50 & 96.11 & 95.69 \\
\hline $\begin{array}{l}\mathrm{P} \text { apfu } \\
\mathrm{Si}\end{array}$ & $\begin{array}{l}0.976 \\
0.024\end{array}$ & $\begin{array}{l}0.960 \\
0.040\end{array}$ & $\begin{array}{l}0.945 \\
0.055\end{array}$ & $\begin{array}{l}0.917 \\
0.083\end{array}$ & $\begin{array}{l}0.932 \\
0.068\end{array}$ & $\begin{array}{l}0.970 \\
0.030\end{array}$ \\
\hline $\begin{array}{l}\text { Th } \\
\text { U } \\
Y \\
\mathrm{Ca} \\
\mathrm{Ce} \\
\mathrm{Pr} \\
\mathrm{Nd} \\
\mathrm{Sm} \\
\mathrm{Gd} \\
\mathrm{Tb} \\
\mathrm{Dy} \\
\mathrm{Ho} \\
\mathrm{Er} \\
\mathrm{T} \\
\mathrm{Y} \\
\mathrm{Cb} \\
\mathrm{Lu} \\
\mathrm{Ca} \\
\mathrm{Pb}\end{array}$ & $\begin{array}{l}0.035 \\
0.002 \\
0.019 \\
0.184 \\
0.398 \\
0.011 \\
0.173 \\
0.037 \\
0.027 \\
0.001 \\
0.007 \\
0.003 \\
0.002 \\
0.075 \\
0.001 \\
0.000 \\
0.009 \\
0.001\end{array}$ & $\begin{array}{l}0.061 \\
0.004 \\
0.020 \\
0.183 \\
0.359 \\
0.009 \\
0.166 \\
0.041 \\
0.029 \\
0.000 \\
0.008 \\
0.000 \\
0.001 \\
0.010 \\
0.000 \\
- \\
0.013 \\
-\end{array}$ & $\begin{array}{l}0.071 \\
0.003 \\
0.017 \\
0.211 \\
0.406 \\
0.008 \\
0.150 \\
0.030 \\
0.023 \\
0.000 \\
0.006 \\
0.001 \\
0.000 \\
0.030 \\
0.003 \\
0.000 \\
0.013 \\
0.001\end{array}$ & $\begin{array}{l}0.099 \\
0.004 \\
0.021 \\
0.148 \\
0.341 \\
- \\
0.205 \\
0.066 \\
0.031 \\
0.001 \\
0.011 \\
- \\
0.002 \\
0.053 \\
0.008 \\
- \\
0.007 \\
0.001\end{array}$ & $\begin{array}{l}0.061 \\
0.002 \\
0.036 \\
0.178 \\
0.389 \\
- \\
0.177 \\
0.034 \\
0.019 \\
0.000 \\
0.009 \\
0.001 \\
0.004 \\
0.010 \\
0.000 \\
- \\
0.005 \\
0.000\end{array}$ & $\begin{array}{l}0.060 \\
0.003 \\
0.015 \\
0.181 \\
0.372 \\
- \\
0.168 \\
0.066 \\
0.036 \\
0.003 \\
0.010 \\
- \\
- \\
0.100 \\
- \\
- \\
0.036 \\
-\end{array}$ \\
\hline Total & 0.985 & 0.904 & 0.973 & 0.998 & 0.925 & 1.05 \\
\hline
\end{tabular}

Structural formula calculated based on $\mathrm{P}+\mathrm{Si}=1$ atoms per formula unit (aplu) -: below detection limits. Electron-microprobe data. 

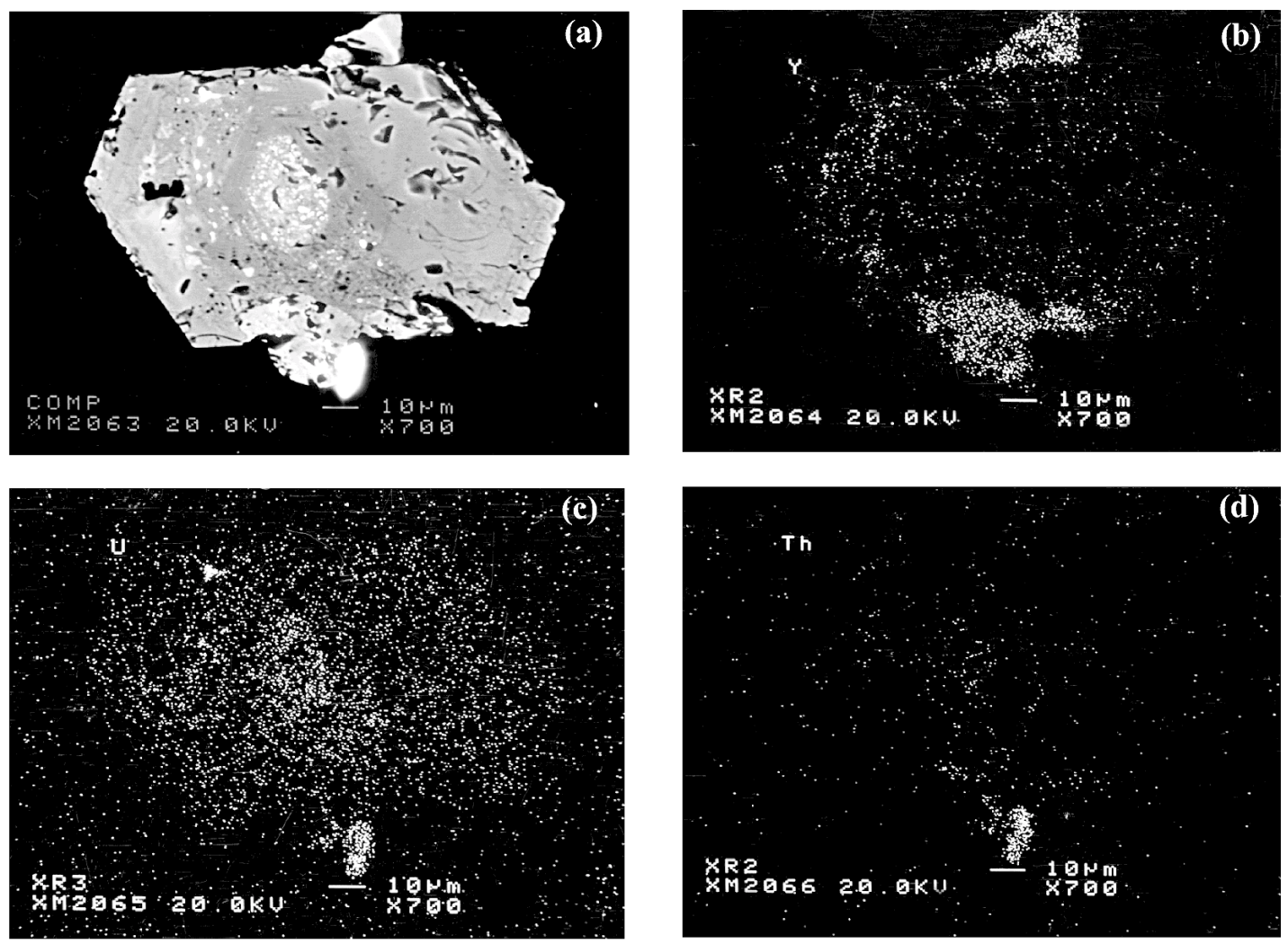

FIG. 8. Zoned crystal of zircon. (a). Back-scattered electron image. (b-d). Distribution maps of Y, U and Th. Note that the porous core has up to $4.81 \mathrm{wt} \% \mathrm{UO}_{2}$, and contains micro-inclusions of uraninite. The rim is relatively rich in Hf. Around the zircon are the associated xenotime II and thorite II. e. Map of the crystal, with results of analyses.

TABLE 8. REPRESENTATIVE COMPOSITIONS OF URANINITI FROM THE XIHUASHAN GRANITIC COMPLEX, CHINA

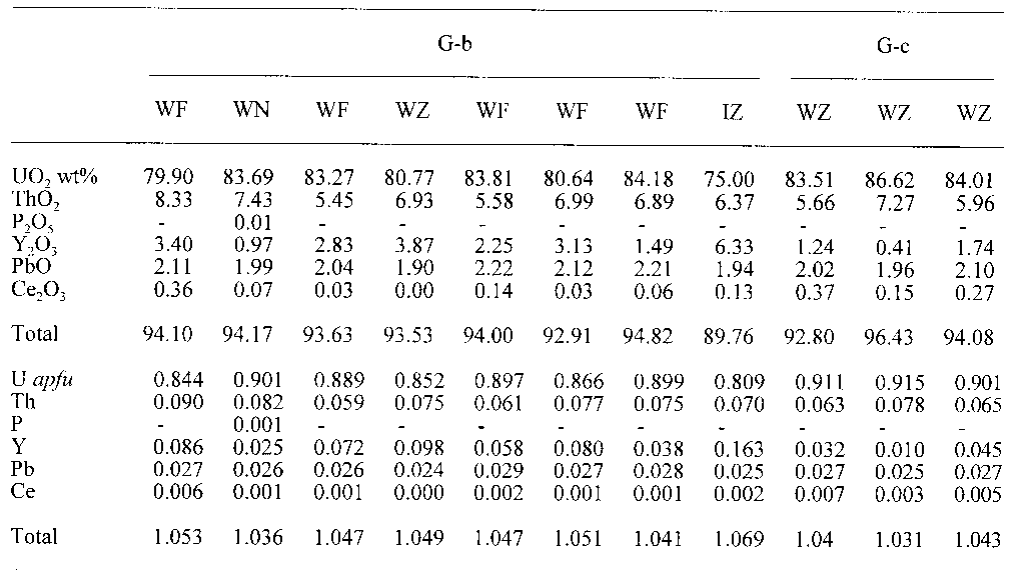

Structural formula calculated on the basis of $\mathrm{O}=2$ atoms per formula unit (apfu). -: below detection limits. WF: intergrown with fergusonite-(Y); WZ: intergrown with zircon; IZ: inclusion in zircon. Electron-microprobe data. 


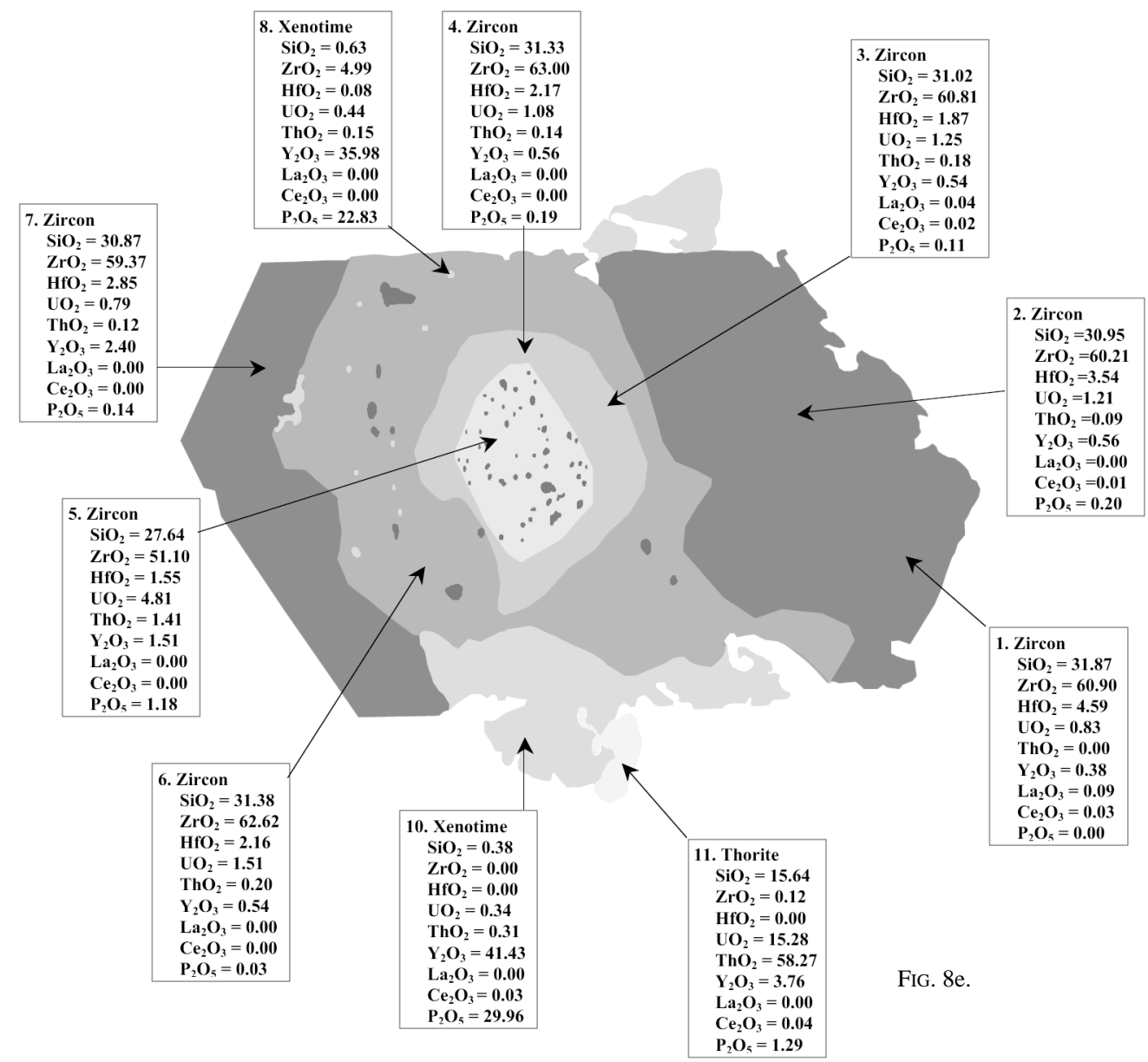

tributed along cleavage planes (Fig. 2c). Representative electron-microprobe data for synchysite-(Y) are shown in Table 2. Owing to small dimensions of the grains, it is difficult to assess the compositional homogeneity on back-scattered electron images. However, electron-microprobe analyses demonstrate compositional variability from one spot to another with respect to the proportion of the Y, LREE and HREE. Concentrations of $L R E E$ oxide vary from 0.72 to $13.99 \mathrm{wt} \%$, and that of the HREE oxide, from 4.08 to $16.74 \mathrm{wt} \%$. Uranium and thorium are very low in synchysite-(Y), generally less than $0.3 \mathrm{wt} \%$ in terms of the oxides.

\section{Uraninite}

In the Xihuashan granitic complex, uraninite is present as an important accessory mineral in the G-b and $\mathrm{G}-\mathrm{c}$ granites. Uraninite did not crystallize in the $\mathrm{G}-$ a granite, because uranium was incorporated in the uranoan thorite $\left(25 \mathrm{wt} \% \mathrm{UO}_{2}\right)$, which is more stable than uraninite at temperatures above $350^{\circ} \mathrm{C}$ (Cuney \& Friedrich 1987). It occurs in three different modes in the $\mathrm{G}-\mathrm{b}$ and $\mathrm{G}-\mathrm{c}$ granites: (1) intergrown with fergusonite (Fig. 11), (2) as micro-inclusions in zircon or spessartine (Fig. 8), and (3) associated with zircon.

Representative compositions of uraninite are reported in Table 8 and Figure 10. Thorium is the major trace element in the structure; irrespective of the mineral association, uraninite has commonly incorporated Th in the range of 2.71 to $8.38 \mathrm{wt} \%$, mostly more than $5 \mathrm{wt} \%$. Th-rich uraninite may crystallize in equilibrium with uranoan thorite, as demonstrated in phase assemblages in the system $\mathrm{SiO}_{2}-\mathrm{UO}_{2}-\mathrm{ThO}_{2}$ (Zimmer 1986). Yttrium is invariably present in uraninite, with from 0.4 to $6.33 \mathrm{wt} \% \mathrm{Y}_{2} \mathrm{O}_{3}$, but generally in the range of $1-3$ $\mathrm{wt} \% \mathrm{Y}_{2} \mathrm{O}_{3}$. The $\mathrm{P}$ content is generally much less than $0.1 \mathrm{wt} \% \mathrm{P}_{2} \mathrm{O}_{5}$, and in some cases even below the level of detection. Uraninite contains around $2 \mathrm{wt} \% \mathrm{PbO}$ $(1.85<\mathrm{PbO}<2.27 \mathrm{wt} \%)$. 


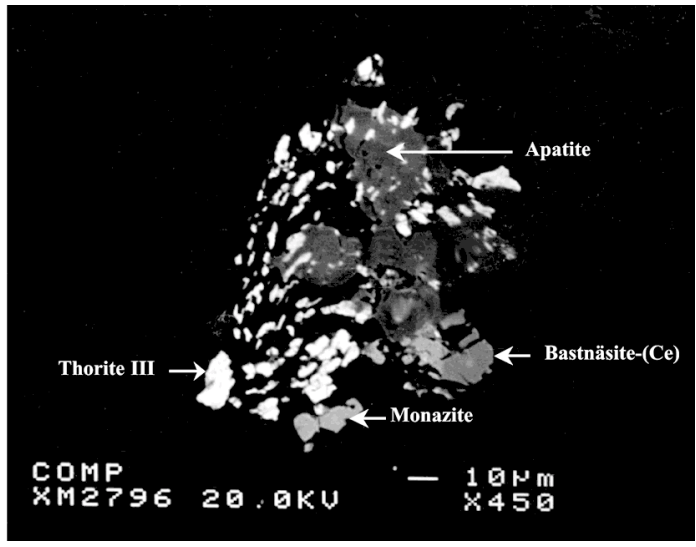

FIG. 9. Back-scattered electron image showing association of thorite III, apatite and bastnäsite-(Ce), derived from the breakdown of monazite.

\section{Pyrochlore-group mineral}

A pyrochlore-group mineral is only found in association with thorite in the G-b granite. Its composition is characterized by (wt\%): $27.39-31.46 \mathrm{Nb}_{2} \mathrm{O}_{5}, 2.86-$ 5.25 $\mathrm{Ta}_{2} \mathrm{O}_{5}, 23.62-30.33 \mathrm{PbO}, 2.75-3.37 \mathrm{WO}_{3}, 4.49$ $5.68 \mathrm{Y}_{2} \mathrm{O}_{3}, 4.95-5.61(R E E)_{2} \mathrm{O}_{3}, 2.57-2.89 \mathrm{wt} \% \mathrm{ThO}_{2}$ (Table 9). The elevated content of $\mathrm{Pb}$ allows us to define it as plumbopyrochlore. This mineral has been recently noted in the Rutherford \#2 pegmatite, in Virginia (Lumpkin 1998) and in the Laoshan A-type granite, China (Wang et al. 2001). In rare-metal-enriched granites, uranmicrolite may be present where the granite has a high Ta:U ratio, e.g., in the Beauvoir granite (Cuney et al. 1992) or in the Yichun granite (Huang et al. 2002). In contrast, when $\mathrm{Ta} / \mathrm{U}$ is low, a pyrochlore-group mineral forms instead, as in the case of the Xihuashan granites $(0.27<\mathrm{Ta} / \mathrm{U}<0.57)$.

\section{Fergusonite- $(Y)$}

Fergusonite-( $\mathrm{Y})$ is the major depository for $\mathrm{Nb}$ in the Xihuashan granites. It occurs commonly as discrete crystals in the G-b granite, but also as micro-inclusions in spessartine from the $\mathrm{G}-\mathrm{b}$ and $\mathrm{G}-\mathrm{c}$ granites. In both cases, it is ubiquitous in its association with uraninite (Fig. 11). Representative compositions of fergusonite$(\mathrm{Y})$ are given in Table 10. Analytical data indicate that fergusonite-( $(\mathrm{Y})$ from the Xihuashan granite contains as much as $1.2-5.53 \% \mathrm{WO}_{3}, 1.32-4.19 \% \mathrm{Ta}_{2} \mathrm{O}_{5}, 0.28$ $3.17 \% \mathrm{ThO}_{2}$, and $0.55-2.23 \% \mathrm{UO}_{2}$.

\section{Ferberite-hübnerite}

Ferberite-hübnerite is observed in the G-a granite and also in the $\mathrm{G}-\mathrm{b}$ granite. It is included in scheelite in the $\mathrm{G}-\mathrm{b}$ granite. That in the $\mathrm{G}-\mathrm{a}$ granite exhibits a progressive core-to-rim zoning characterized by increasing amounts of Fe together with decreasing amounts of Mn. $\mathrm{Nb}$ content reaches up to $1.18 \mathrm{wt} \% \mathrm{Nb}_{2} \mathrm{O}_{5}$ (No. 5, Table 11).

\section{Unidentified $N b-T a-W$ mineral}

An unidentified niobotantalate mineral $(\sim 30 \mu \mathrm{m}$ in size) has been found in association with uraninite and zircon in the G-b granite (Fig. 12). A representative composition is given in Table 9 (No. 4). Nb, Ta, W, Y, $\mathrm{U}$ and $\mathrm{Th}$ are major components of this mineral. It contains exceptionally up to $15 \mathrm{wt} \% \mathrm{WO}_{3}$. This mineral is most likely a pyrochlore-group mineral, but because of the lack of X-ray data, this hypothesis cannot be confirmed.

\section{Scheelite}

Scheelite appears in the G-b granite, where it is associated with ferberite. It is also found as one of the assemblage of alteration products of yttrian fluorite in the G-c granite (Fig. 13). Apart from low contents of $\mathrm{Fe}$ and $\mathrm{Mn}$, the electron-microprobe results correspond well to the stoichiometry of scheelite (Table 11). A high tungsten-carrying capacity in the granitic melt or

\begin{tabular}{|c|c|c|c|c|c|c|c|c|c|}
\hline & & $\begin{array}{l}\text { Plumbo } \\
\text { yrochlo }\end{array}$ & & $\begin{array}{l}\text { Nb-la-W } \\
\text { phase }\end{array}$ & & & $\begin{array}{l}\text { Plumbo- } \\
\text { yrochlor }\end{array}$ & $\mathrm{Nb}$ & $\begin{array}{c}\text { o-Ta-W } \\
\text { phase }\end{array}$ \\
\hline & l & 2 & 3 & 4 & & 1 & 2 & 3 & 4 \\
\hline $\mathrm{Y}_{2} \mathrm{O}_{3} \mathrm{wt} \%$ & 4.49 & 5.22 & 5.68 & 6.52 & Ү apfu & 0.308 & 0.356 & 0.428 & 0.410 \\
\hline $\mathrm{La}_{2} \mathrm{O}_{3}$ & - & - & 0.06 & 0.15 & $\mathrm{la}$ & 0.079 & 0.043 & 0.049 & 0.007 \\
\hline $\mathrm{Ce}_{2} \mathrm{O}_{3}$ & 1.76 & 0.97 & 1.00 & 0.13 & $\mathrm{Ce}$ & 0.000 & 0.000 & 0.000 & 0.006 \\
\hline $\mathrm{Nd}_{2} \mathrm{O}_{3}$ & 0.47 & 0.68 & 0.32 & 0.20 & $\mathrm{Nd}$ & 0.020 & 0.030 & 0.015 & 0.008 \\
\hline $\mathrm{Sm}_{2} \mathrm{O}_{3}^{\circ}$ & - & - & - & 0.40 & $\mathrm{Sm}$ & 0.000 & 0.000 & 0.000 & 0.016 \\
\hline $\mathrm{Gd}_{2} \mathrm{O}_{3}$ & 1.05 & 1.42 & 1.67 & 2.12 & $\mathrm{Gd}$ & 0.043 & 0.057 & 0.074 & 0.083 \\
\hline $\mathrm{Ib}_{2} \mathrm{O}_{3}$ & 0.10 & 0.02 & 0.06 & 0.27 & $\mathrm{~Tb}$ & 0.004 & 0.001 & 0.003 & 0.010 \\
\hline $\mathrm{Dy}_{2} \mathrm{O}_{3}$ & 0.34 & 0.70 & 0.93 & 2.38 & Dy & 0.013 & 0.027 & 0.040 & 0.091 \\
\hline $\mathrm{Ho}_{2} \mathrm{O}_{3}$ & 0.14 & 0.27 & 0.31 & 0.95 & Ho & 0.005 & 0.010 & 0.013 & 0.036 \\
\hline $\mathrm{Er}_{2} \mathrm{O}_{3}$ & 0.03 & 0.22 & - & 2.90 & Er & 0.001 & 0.009 & 0.000 & 0.108 \\
\hline $\mathrm{Tm}_{2} \mathrm{O}_{3}$ & 0.18 & - & - & 0.56 & $\mathrm{Tm}$ & 0.007 & 0.000 & 0.000 & 0.021 \\
\hline $\mathrm{Yb}_{2} \mathrm{O}_{3}$ & 0.83 & 1.11 & 1.11 & 2.78 & $\mathrm{Yb}$ & 0.031 & 0.041 & 0.046 & 0.100 \\
\hline $\mathrm{Iu}_{3} \mathrm{O}_{3}$ & 0.05 & 0.21 & 0.15 & - & $\mathrm{I}, \mathrm{u}$ & 0.002 & 0.008 & 0.006 & - \\
\hline $\mathrm{ThO}_{2}$ & 2.64 & 2.57 & 2.89 & 1.26 & Th & 0.074 & 0.071 & 0.088 & 0.034 \\
\hline $\mathrm{UO}_{2}{ }^{2}$ & 6.03 & 5.65 & 7.80 & 7.23 & I & 0.165 & 0.153 & 0.233 & 0.190 \\
\hline $\mathrm{CaO}$ & 0.41 & 0.35 & 0.48 & 0.42 & $\mathrm{Ca}$ & 0.054 & 0.045 & 0.069 & 0.053 \\
\hline $\mathrm{FeO}$ & 6.05 & 5.56 & 10.90 & 5.09 & $\mathrm{Fe}$ & 0.623 & 0.565 & 1.222 & 0.503 \\
\hline $\mathrm{MnO}$ & 0.01 & 0.05 & 0.05 & 1.34 & $\mathrm{Mn}$ & 0.001 & 0.005 & 0.006 & 0.134 \\
\hline $\mathrm{PbO}$ & 30.33 & 29.08 & 23.62 & 0.50 & $\mathrm{~Pb}$ & 1.006 & 0.951 & 0.853 & 0.016 \\
\hline $\mathrm{SiO}_{2}$ & 3.81 & 3.36 & 3.76 & 0.76 & $\mathrm{Si}$ & 0.469 & 0.408 & 0.504 & 0.090 \\
\hline $\mathrm{P}_{2} \mathrm{O}_{5}^{2}$ & 0.07 & 0.05 & 0.10 & - & $\mathrm{P}$ & 0.007 & 0.005 & 0.011 & - \\
\hline $\mathrm{Nb}_{2} \mathrm{O}_{5}$ & 31.46 & 31.92 & 27.39 & 26.13 & & & & & \\
\hline $\mathrm{Ta}_{2} \mathrm{O}_{5}^{-}$ & 3.54 & 2.86 & 5.25 & 18.57 & Total & 2.912 & 2.785 & 3.66 & 1.916 \\
\hline $\mathrm{TiO}_{2}$ & 0.45 & 0.51 & 0.40 & 0.09 & $\mathrm{Nb}$ & 1.752 & 1.753 & 1.660 & 1.395 \\
\hline $\mathrm{WO}_{3}$ & & 3.37 & 3.11 & 14.22 & $\mathrm{Ta}$ & 0.118 & 0.094 & 0.191 & 0.597 \\
\hline & 1.25 & 0.21 & 0.61 & 0.08 & $\mathrm{Ti}$ & 0.000 & 0.000 & 0.003 & 0.008 \\
\hline$-F=0$ & 0.52 & 0.09 & 0.26 & 0.03 & W & 0.485 & 0.081 & 0.259 & 0.435 \\
\hline Total & 97.68 & 96.26 & 97.38 & 95.02 & $\Gamma$ & 0.042 & 0.046 & 0.040 & 0.030 \\
\hline
\end{tabular}

Structural formula are calculated on the basis of $\mathrm{Nb}+\mathrm{Ta}+\mathrm{Ti}+\mathrm{W}=2$ atoms per formula unit $(a p f u)$. -: below detection limits. Electron-microprobe data. 
TABLE 10. REPRESENTATIVE COMPOSITIONS OF FERGUSONITE-(Y) FROM THE G-b AND G-c UNITS OF THE XIHUASHAN GRANITIC COMPLEX, CHINA

\begin{tabular}{|c|c|c|c|c|c|c|c|c|c|c|c|c|c|c|c|c|c|}
\hline \multicolumn{6}{|c|}{$\mathrm{G}-\mathrm{b}$} & \multicolumn{3}{|c|}{ G-c } & \multicolumn{6}{|c|}{$\mathrm{G}-\mathrm{b}$} & \multicolumn{3}{|c|}{$\mathrm{G}-\mathrm{c}$} \\
\hline 1 & 2 & 3 & 4 & 5 & 6 & 7 & 8 & 9 & 1 & 2 & 3 & 4 & 5 & 6 & 7 & 8 & 9 \\
\hline
\end{tabular}

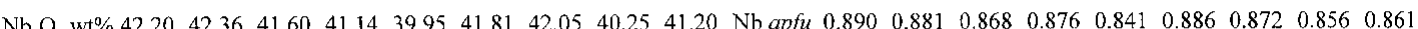
$\begin{array}{lllllllllll}0.051 & 0.049 & 0.053 & 0.020 & 0.021 & 0.032 & 0.037 & 0.017 & 0.020\end{array}$ $\begin{array}{llllllllllll}\mathrm{Ta}_{2} \mathrm{O}_{5} & 4.05 & 3.93 & 4.19 & 1.57 & 1.64 & 2.52 & 2.93 & 1.32 & 1.61 & \mathrm{Ta}\end{array}$ $\begin{array}{lllllllllllll}\mathrm{Y}_{2} \mathrm{O}_{3} & 27.07 & 27.31 & 27.65 & 31.54 & 32.83 & 27.98 & 26.68 & 28.51 & 29.75 & \mathrm{Y}\end{array}$ $\begin{array}{lllllllllll}\mathrm{La}_{2} \mathrm{O}_{3} & - & 0.11 & 0.02 & - & - & 0.05 & 0.03 & - & - & \mathrm{La}\end{array}$

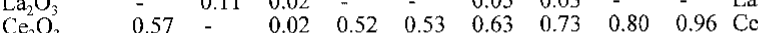
$\begin{array}{lllllllllll}\mathrm{Nd}_{2} \mathrm{O}_{3} & 0.14 & - & 0.57 & 0.74 & 0.79 & 1.75 & 0.67 & 1.07 & 0.85 & \mathrm{Nd}\end{array}$

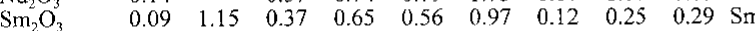
$\begin{array}{llllllllll}\mathrm{Gd}_{2} \mathrm{O}_{3} & 4.41 & 3.15 & 3.82 & 3.04 & 3.00 & 5.17 & 4.79 & 3.73 & 4.12 \\ \mathrm{Td}\end{array}$

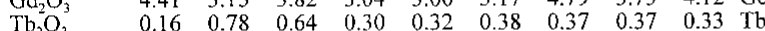
$\begin{array}{lllllllllll}\mathrm{Tb}_{2} \mathrm{O}_{3} & 0.16 & 0.78 & 0.64 & 0.30 & 0.32 & 0.38 & 0.37 & 0.37 & 0.33 & \mathrm{~Tb} \\ \mathrm{Dy}_{2} \mathrm{O}_{3} & 3.55 & 4.66 & 4.77 & 3.66 & 3.61 & 5.86 & 5.21 & 3.19 & 3.30 & \mathrm{Dy}\end{array}$

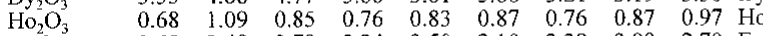

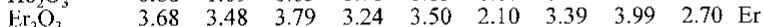
$\begin{array}{lllllllllll}\mathrm{Tm}_{2} \mathrm{O}_{3} & 0.24 & 0.41 & 0.51 & 0.31 & 0.39 & 0.45 & 0.54 & 0.38 & 0.65 & \mathrm{Tm}\end{array}$

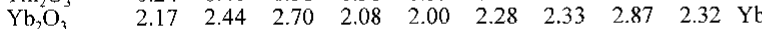
$\begin{array}{lllllllllll}\mathrm{Lu}_{2} \mathrm{O}_{3} & 0.93 & 0.93 & 0.43 & 0.72 & 0.49 & 0.89 & 0.23 & 0.35 & 0.42 & \mathbf{L u}\end{array}$ $\begin{array}{llllllllll}\mathrm{ThO}_{2} & 2.14 & 0.64 & 0.29 & 2.47 & 2.63 & 1.36 & 0.89 & 3.17 & 0.52 \\ \mathrm{Th}\end{array}$ $\begin{array}{lllllllllll}\mathrm{UO}_{2} & 1.14 & 2.23 & 2.04 & 1.22 & 1.30 & 0.78 & 0.55 & 1.61 & 0.59 & \mathrm{U}\end{array}$ $\begin{array}{lllllllllll}\mathrm{CaO} & 0.55 & 0.42 & 0.31 & 0.93 & 0.63 & 0.42 & 0.44 & 0.50 & 0.35 & \mathrm{Ca}\end{array}$ $\begin{array}{llllllllllll}\mathrm{FeO} & 0.17 & - & - & 0.69 & 0.63 & 0.44 & 1.02 & 0.64 & 1.28 \mathrm{Fe}\end{array}$

$\begin{array}{lllllllllll}\mathrm{MnO} & 0.02 & 0.03 & 0.04 & 0.12 & 0.14 & 0.04 & 1.86 & 0.95 & 1.74 & \mathrm{Mn}\end{array}$

$\begin{array}{lllllllllll}\mathrm{PbO} & 0.50 & 0.44 & 0.62 & 0.67 & 0.77 & 0.64 & 0.56 & 0.66 & 0.58 & \mathrm{~Pb}\end{array}$

$\begin{array}{lllllllllll}\mathrm{P}_{2} \mathrm{O}_{5} & 0.09 & - & - & 0.01 & 0.09 & 0.03 & 0.01 & 0.09 & - & \mathrm{P} \\ \mathrm{WO}_{3} & 4.01 & 5.14 & 5.53 & 1.20 & 2.87 & 1.98 & 4.31 & 3.58 & 4.24 & \mathrm{~W}\end{array}$ $\begin{array}{llllllllll}0.051 & 0.049 & 0.053 & 0.020 & 0.021 & 0.032 & 0.037 & 0.017 & 0.020 \\ 0.672 & 0.668 & 0.679 & 0.790 & 0.813 & 0.698 & 0.651 & 0.714 & 0.732\end{array}$ $\begin{array}{lllllllll}0.672 & 0.668 & 0.679 & 0.790 & 0.813 & 0.698 & 0.651 & 0.71 \\ - & 0.002 & 0.000 & - & - & 0.001 & 0.001 & \text { - }\end{array}$ $\begin{array}{llllllllll}0.010 & 0.000 & 0.000 & 0.009 & 0.009 & 0.011 & 0.012 & 0.014 & 0.016\end{array}$ $\begin{array}{llllllllll}0.002 & 0.000 & 0.009 & 0.012 & 0.013 & 0.029 & 0.011 & 0.018 & 0.014\end{array}$ $\begin{array}{llllllllll}0.001 & 0.018 & 0.006 & 0.011 & 0.009 & 0.016 & 0.002 & 0.004 & 0.005\end{array}$ $\begin{array}{llllllllll}0.068 & 0.048 & 0.058 & 0.047 & 0.046 & 0.080 & 0.073 & 0.058 & 0.063\end{array}$ $\begin{array}{llllllllll}0.002 & 0.012 & 0.010 & 0.005 & 0.005 & 0.006 & 0.006 & 0.006 & 0.005\end{array}$ $\begin{array}{lllllllll}0.053 & 0.069 & 0.071 & 0.056 & 0.054 & 0.088 & 0.077 & 0.048 & 0.049\end{array}$ $\begin{array}{llllllllll}0.010 & 0.016 & 0.012 & 0.011 & 0.012 & 0.013 & 0.011 & 0.013 & 0.014\end{array}$ $\begin{array}{llllllllll}0.054 & 0.050 & 0.055 & 0.048 & 0.051 & 0.031 & 0.049 & 0.059 & 0.039\end{array}$ $\begin{array}{llllllllll}0.003 & 0.006 & 0.007 & 0.005 & 0.006 & 0.007 & 0.008 & 0.006 & 0.009\end{array}$ $\begin{array}{llllllllll}0.031 & 0.034 & 0.038 & 0.030 & 0.028 & 0.033 & 0.033 & 0.041 & 0.033\end{array}$ $\begin{array}{llllllllll}0.013 & 0.013 & 0.006 & 0.010 & 0.007 & 0.013 & 0.003 & 0.005 & 0.006\end{array}$ $\begin{array}{llllllllll}0.023 & 0.007 & 0.003 & 0.026 & 0.028 & 0.014 & 0.009 & 0.034 & 0.005\end{array}$ $\begin{array}{llllllllll}0.012 & 0.023 & 0.021 & 0.013 & 0.013 & 0.008 & 0.006 & 0.017 & 0.006\end{array}$ $\begin{array}{lllllllll}0.027 & 0.021 & 0.015 & 0.047 & 0.031 & 0.021 & 0.022 & 0.025 & 0.017\end{array}$ $\begin{array}{llllllllll}0.007 & 0.000 & 0.000 & 0.027 & 0.025 & 0.017 & 0.039 & 0.025 & 0.050\end{array}$ $\begin{array}{llllllllll}0.001 & 0.001 & 0.002 & 0.005 & 0.005 & 0.002 & 0.072 & 0.038 & 0.068\end{array}$ $\begin{array}{llllllllll}0.006 & 0.005 & 0.008 & 0.009 & 0.010 & 0.008 & 0.007 & 0.008 & 0.007\end{array}$ $\begin{array}{lllllllll}0.004 & 0.000 & 0.000 & 0.001 & 0.004 & 0.001 & 0.000 & 0.004\end{array}$ $\begin{array}{lllllllll}0.048 & 0.061 & 0.066 & 0.015 & 0.035 & 0.024 & 0.051 & 0.044 & 0.051\end{array}$

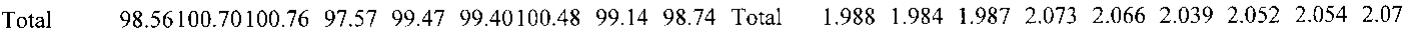

Structural formula calculated on the basis of $\mathrm{O}=4$ atoms per formula unit (apfu). - : below detection limits. Electron-microprobe data.

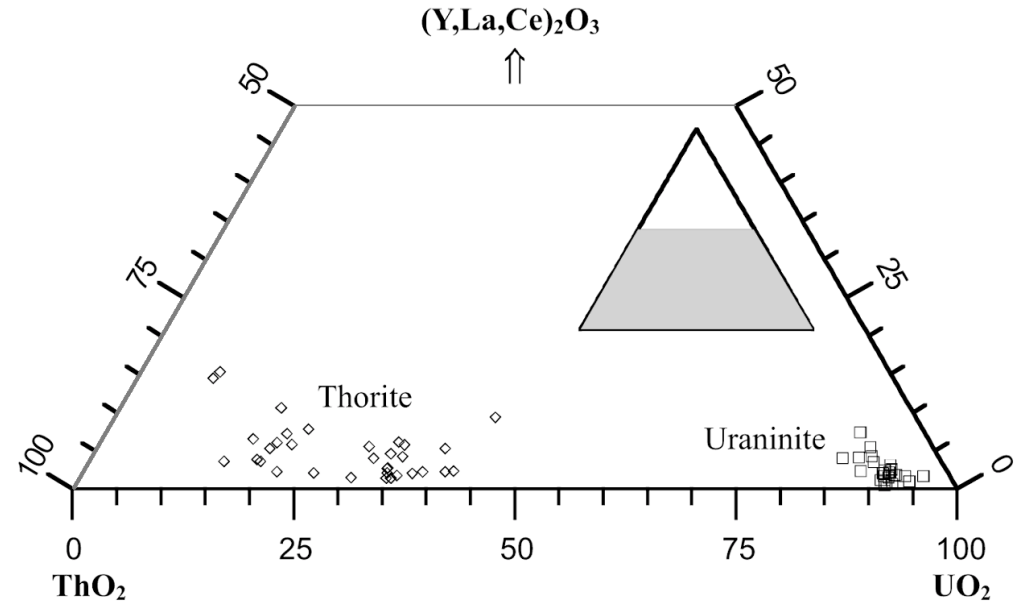

FIG. 10. Plot of compositions of thorite and uraninite in the triangular diagram $\mathrm{ThO}_{2}-$ $\mathrm{UO}_{2}-(\mathrm{Y}, \mathrm{La}, \mathrm{Ce})_{2} \mathrm{O}_{3}(\mathrm{wt} \%)$.

postmagmatic fluid at Xihuashan is also indicated by the presence of $\mathrm{W}$-bearing niobotantalates and associated ferberite-hübnerite.

\section{Discussion}

From trace-element and isotopic data, Maruéjol et al. (1990) have suggested that the different units of the Xihuashan complex appear to be cogenetic, and further 


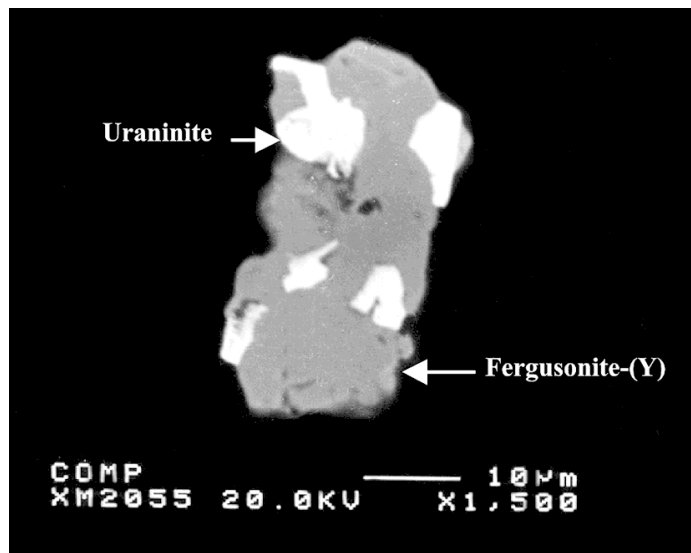

FIG. 11. Intergrowth of fergusonite-(Y) and uraninite. Backscattered electron image.

pointed out a magmatic evolution from the $\mathrm{G}-\mathrm{a}$ granite to the $\mathrm{G}-\mathrm{b}$ and $\mathrm{G}-\mathrm{c}$ granites by simple fractionation, with a later overprint of hydrothermal alteration in the G-b granite. In this study, we give mineralogical evidence for the magmatic-hydrothermal evolution of the Xihuashan granitic complex.

The accessory-mineral associations of the Xihuashan granitic complex are summarized in Table 12. Early accessory phases crystallizing at the magmatic stage are principally yttrian fluorite, spessartine, zircon, monazite-(Ce), xenotime-(Y), fergusonite-(Y), gadolinite$(\mathrm{Y})$, uraninite and uranoan thorite. However, these minerals experienced further evolution at the late-magmatic and hydrothermal stage.

The G-a granite is mostly composed of quartz, feldspars and biotite. The REE possess very low partition coefficients for these minerals. Monazite-(Ce) is a stable mineral phase that fractionates very early because of its very low solubility in peraluminous melts, which leads to a magma rapidly depleted in LREE, but enriched in HREE (Rapp \& Watson 1986, Wark \& Miller 1993). Crystallization of abundant monazite in the $\mathrm{G}-$ a granite caused the depletion in LREE in the G-b and G-c granites, as demonstrated by the scarcity of monazite-(Ce). This mineral may be surrounded by bastnäsite-(Ce), thorite and fluorapatite in the G-b and G-c granites. The work of Ayers \& Watson (1991) and of Williams-Jones $\&$ Wood (1992) indicates that monazite is significantly soluble at very low $\mathrm{pH}$ and high fluoride activity, and the stability of bastnäsite increases with increasing activity of $\mathrm{CO}_{3}{ }^{2-}$. Thus, the textural relationship between monazite-(Ce) and bastnäsite-(Ce) may be attributed to hydrothermal alteration of magmatic Th-bearing monazite in presence of fluid enriched in $\mathrm{F}$ and $\mathrm{CO}_{2}$ via the following reaction:

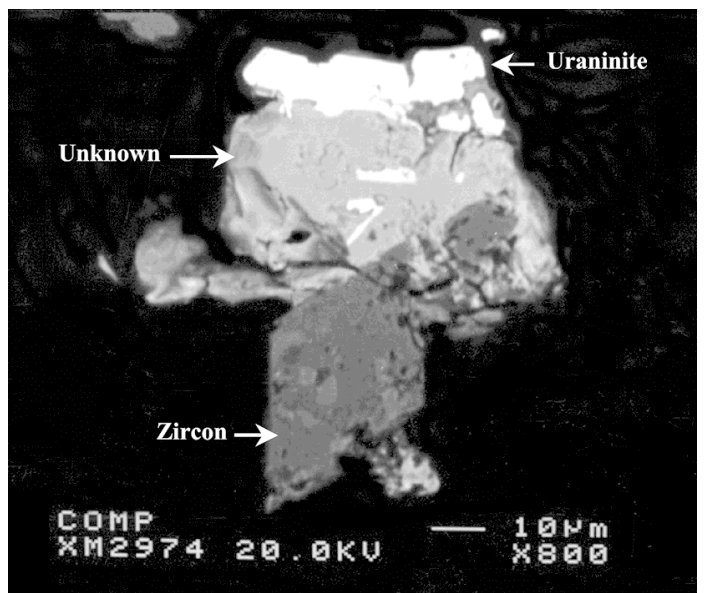

FIG. 12. Unidentified niobotantalate. The back-scattered electron image illustrates its intimate association with zircon and uraninite.

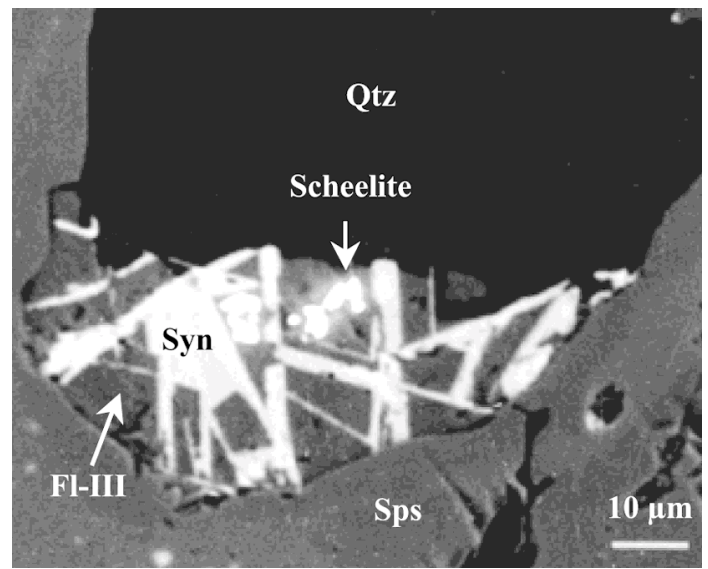

FIG. 13. Back-scattered electron image showing small crystals of scheelite associated with fluorite III (Fl-III) and synchysite-(Y) (Syn). Qtz: quartz, Sps: spessartine.

$$
\begin{aligned}
& 3\left(\mathrm{Ce}_{1-a} \mathrm{Th}_{a}\right)\left(\mathrm{P}_{1-a} \mathrm{Si}_{a}\right) \mathrm{O}_{4} \\
& \text { Thorian monazite-(Ce) } \\
& +(5-5 a) \mathrm{Ca}^{2+}+(3-3 a) \mathrm{CO}_{3}{ }^{2-}+(4-4 a) \mathrm{F}^{-} \\
& \text {Hydrothermal fluid } \\
& \Rightarrow(3-3 a) \mathrm{Ce}\left(\mathrm{CO}_{3}\right) \mathrm{F}+3 a \mathrm{ThSiO}_{4} \\
& \text { Bastnäsite-(Ce) Thorite } \\
& +(1-a) \mathrm{Ca}_{5}\left(\mathrm{PO}_{4}\right)_{3} \mathrm{~F} \\
& \text { Fluorapatite }
\end{aligned}
$$

In peraluminous magmas, $\mathrm{Zr}, R E E$, Th, $\mathrm{U}, \mathrm{Y}, \mathrm{P}$ possess a very high solubility, and therefore have strong 
TABLE 11. COMPOSITION OF TUNGSTEN MINERALS

FROM THE XIHUASHAN GRANITIC COMPIEX, CHINA

\begin{tabular}{|c|c|c|c|c|c|c|c|c|c|c|c|c|c|}
\hline & \multicolumn{4}{|c|}{ Scheelite } & \multicolumn{8}{|c|}{ Ferbcrite-hübnerite } & \multirow[b]{2}{*}{11} \\
\hline & 1 & 2 & 3 & 4 & 5 & 6 & 7 & $8 \mathrm{C}$ & $8 \mathrm{R}$ & $9 \mathrm{C}$ & $9 \mathrm{R}$ & 10 & \\
\hline $\begin{array}{l}\mathrm{Nb}_{2} \mathrm{O}_{5} \mathrm{wt}^{\mathrm{T}} \\
\mathrm{Ta}_{2} \mathrm{O}_{5} \\
\mathrm{WO}_{3} \\
\mathrm{FeO} \\
\mathrm{MnO} \\
\mathrm{CaO}\end{array}$ & $\begin{array}{r}- \\
0.02 \\
80.52 \\
0.17 \\
0.21 \\
19.31\end{array}$ & $\begin{array}{r}- \\
0.03 \\
80.59 \\
0.26 \\
0.26 \\
19.23\end{array}$ & $\begin{array}{r}0.02 \\
- \\
80.53 \\
0.09 \\
0.09 \\
18.75\end{array}$ & $\begin{array}{r}- \\
0.05 \\
80.30 \\
0.03 \\
0.07 \\
18.82\end{array}$ & $\begin{array}{r}1.18 \\
0.16 \\
74.64 \\
14.25 \\
9.22 \\
0.02\end{array}$ & $\begin{array}{r}0.61 \\
0.15 \\
75.09 \\
5.73 \\
17.64 \\
0.04\end{array}$ & $\begin{array}{r}1.01 \\
0.30 \\
74.60 \\
10.74 \\
12.48 \\
0.03\end{array}$ & $\begin{array}{r}0.22 \\
0.11 \\
75.66 \\
15.22 \\
7.62 \\
-\end{array}$ & $\begin{array}{r}0.51 \\
0.13 \\
75.88 \\
16.18 \\
6.83 \\
-\end{array}$ & $\begin{array}{c}0.18 \\
- \\
77.06 \\
15.71 \\
7.93 \\
-\end{array}$ & $\begin{array}{r}0.38 \\
0.11 \\
75.207 \\
16.44 \quad 1 \\
6.95 \\
0.04\end{array}$ & $\begin{array}{r}0.58 \\
- \\
75.93 \\
15.58 \\
8.10 \\
0.05\end{array}$ & $\begin{array}{r}0.51 \\
0.11 \\
76.12 \\
15.57 \\
7.89 \\
0.07\end{array}$ \\
\hline Total & 100.221 & 100.37 & 99.48 & 99.27 & 99.46 & 99.26 & 99.16 & 98.82 & 99.5310 & 100.89 & 99.1210 & 100.241 & 100.26 \\
\hline $\begin{array}{l}\text { Nb apfu } \\
\text { Ta } \\
\text { W } \\
\mathrm{Fe} \\
\mathrm{Mn} \\
\mathrm{Ca}\end{array}$ & $\begin{array}{l}- \\
0.000 \\
0.998 \\
0.007 \\
0.009 \\
0.990\end{array}$ & $\begin{array}{ll}0 & 0.000 \\
8 & 0.998 \\
7 & 0.010 \\
9 & 0.011 \\
0 & 0.985\end{array}$ & $\begin{array}{ll}0.000 \\
0 \\
8 \\
0 \\
0.007 \\
0.003 \\
1.004 \\
5 & 0.970\end{array}$ & $\begin{array}{ll}0 & - \\
& 0.001 \\
7 & 1.006 \\
3 & 0.001 \\
4 & 0.003 \\
0 & 0.975\end{array}$ & $\begin{array}{l}0.027 \\
0.002 \\
0.977 \\
0.602 \\
0.394 \\
0.001\end{array}$ & $\begin{array}{ll}7 & 0.014 \\
2 & 0.002 \\
7 & 0.986 \\
2 & 0.243 \\
4 & 0.757 \\
1 & 0.002\end{array}$ & $\begin{array}{ll}4 & 0.023 \\
2 & 0.004 \\
5 & 0.980 \\
0.455 \\
7 & 0.536 \\
2 & 0.002\end{array}$ & $\begin{array}{ll}3 & 0.005 \\
4 & 0.002 \\
0 & 1.001 \\
5 & 0.650 \\
6 & 0.330 \\
2 & -\end{array}$ & $\begin{array}{l}0.012 \\
20.002 \\
0.996 \\
0.686 \\
0.293 \\
0 \\
-\end{array}$ & $\begin{array}{l}0.004 \\
- \\
0.999 \\
0.657 \\
0.336 \\
-\end{array}$ & $\begin{array}{ll}4 & 0.009 \\
& 0.002 \\
9 & 0.991 \\
7 & 0.699 \\
6 & 0.299 \\
& 0.002\end{array}$ & $\begin{array}{l}0.013 \\
- \\
0.988 \\
0.655 \\
0.344 \\
0.003\end{array}$ & $\begin{array}{ll}3 & 0.012 \\
& 0.001 \\
8 & 0.991 \\
5 & 0.654 \\
4 & 0.336 \\
3 & 0.004\end{array}$ \\
\hline Total & 2.004 & 42.004 & 41.984 & 41.986 & 61.976 & 61.99 & 1.977 & 1.983 & 31.977 & 71.992 & 21.993 & 1.99 & 1.986 \\
\hline $\begin{array}{l}\text { Fbr } \\
\text { Ifbn } \\
\text { Scl }\end{array}$ & $\begin{array}{r}0.66 \\
0.85 \\
98.49\end{array}$ & $\begin{array}{r}1.04 \\
1.05 \\
97.91\end{array}$ & $\begin{array}{r}0.35 \\
0.39 \\
99.25\end{array}$ & $\begin{array}{r}0.14 \\
0.30 \\
99.57\end{array}$ & $\begin{array}{r}60.35 \\
39.54 \\
0.11\end{array}$ & $\begin{array}{r}24.24 \\
75.53 \\
0.24\end{array}$ & $\begin{array}{r}45.87 \\
53.96 \\
0.17\end{array}$ & $\begin{array}{r}66.35 \\
33.65 \\
0.00\end{array}$ & $\begin{array}{r}70.06 \\
29.94 \\
0.00\end{array}$ & $\begin{array}{r}66.16 \\
33.84 \\
0.00\end{array}$ & $\begin{array}{r}69.88 \\
29.92 \\
0.20\end{array}$ & $\begin{array}{r}65.34 \\
34.38 \\
0.28\end{array}$ & $\begin{array}{r}65.85 \\
33.79 \\
0.36\end{array}$ \\
\hline
\end{tabular}

C: core, R: rim; 10 and 11: inclusions in scheelite. Structural formula calculated on the basis of $O=4$ atoms per formula unit (apfiu). All Fe is expressed as $\mathrm{Fe}^{2-} ;--$ below detection limits. Symbols: $\mathrm{Fbr}$ : ferberite, Hbn: hubnerite, Scl: scheelitc. Electron-microprobe data.

TABLF 12. ASSOCIATIONS OF ACCESSORY MINFRALS IN THE. XIIIUASHAN GRANITIC COMPLEX, CHINA

\begin{tabular}{lccc}
\hline Unit & G-a & G-b & G-c \\
\hline Fluorite I & & + & \\
Fluorite II & & + & + \\
Fluorite III & & + & + \\
Spessartine & + & + & + \\
Gadolinitc-(Y) & & + & + \\
Zircon & + & + & + \\
Thorite I & & + & + \\
Thorite II & + & + & + \\
Xenotime-(Y) I & + & + & + \\
Xenotime-(Y) II & & $+(?)$ & + \\
Monazite-(Ce) & & + & + \\
Synchysite-(Y) & & + & + \\
Bastnäsite-(Ce) & & + & + \\
Uraninite & & + & + \\
Fergusonite-(Y) & & + & + \\
Pyrochlore (s.l.) & & + & + \\
Fcrbcrite-hübnerite & & + & + \\
W-Nb-Ta mineral & & & + \\
Scheclite & & & + \\
\hline
\end{tabular}

lithophile behavior (Linnen 1998). Thus large amounts of a wide variety of accessory minerals crystallize more or less simultaneously in most differentiated magma, as in the case of the G-b and G-c granites at Xihuashan. Magmatic zircon crystallized with minute inclusions of xenotime and thorite, which are commonly associated. These phases, with fergusonite-(Y) and gadolinite-(Y), may also occur as inclusions in spessartine. Apart from uranoan thorite, uranium formed significant amounts of uraninite. Commonly, the elevated content of Th determined in uraninite is attributed to equilibrium crystallization of uranoan thorite.

In addition to minute inclusions of $\mathrm{Y}$-bearing minerals, spessartine contains a striking amount of $\mathrm{Y}$ and HREE in its structure, particularly in its central area. This fact suggests that the melt was enriched in $\mathrm{Y}$ and $H R E E$ at an early stage during crystallization of the $\mathrm{G}-$ b and G-c granites, as a result of LREE depletion by crystallization of monazite in the $\mathrm{G}-\mathrm{a}$ granite. The consumption of $\mathrm{Y}$ and HREE leads to a decrease in these elements in the melt, the crystal being impoverished in (or even free of) $\mathrm{Y}$ and HREE at the rim.

Fluorite I (yttrian fluorite) is one of the earliest depositories of $\mathrm{Y}$ and $R E E$ in the $\mathrm{G}-\mathrm{b}$ and $\mathrm{G}-\mathrm{c}$ granites; it contains up to $15 \mathrm{wt} \% \mathrm{Y}_{2} \mathrm{O}_{3}$. However, this phase seems to be unstable in the later fluid-rich environment. Evidence for subsequent alteration of yttrian fluorite is seen as a peripheral association of $\mathrm{Y}$-poor fluorite III and synchysite-( $\mathrm{Y}$ ) in the G-b and G-c granites (Figs. 2a, c). This process may be possibly described by the following reaction:

$$
\begin{aligned}
& \mathrm{Ca}_{1-a} \mathrm{Y}_{a} \mathrm{~F}_{2+a} \\
& \begin{array}{l}
\text { Yttrian fluorite } \\
\text { (Fluorite I) }
\end{array} \\
& \mathrm{CaF}_{2}+a \mathrm{Ca}^{2+}+2 \mathrm{CO}_{3}^{2-} \Rightarrow \\
& \begin{array}{l}
\text { Fluorite } \\
\text { (Fluorite III) }
\end{array}
\end{aligned}
$$


Zircon is a common accessory mineral present throughout the Xihuashan granites, but it varies in composition. In the $\mathrm{G}-\mathrm{a}$ granite, zircon contains on average $2.5 \mathrm{wt} \% \mathrm{HfO}_{2}, 0.38 \% \mathrm{UO}_{2}, 0.1 \% \mathrm{ThO}_{2}$ and $0.49 \%$ $\mathrm{Y}_{2} \mathrm{O}_{3}$, and does not exhibit any textural evidence of zoning. Zircon from the $\mathrm{G}-\mathrm{b}$ and $\mathrm{G}-\mathrm{c}$ granites exhibits zoning, represented by the presence of polymineralic micro-inclusions of xenotime-(Y), thorite and uraninite in the core, and enrichment in Hf at the rim. Significant mobility of Hf was postulated as resulting from hydrothermal transfer induced by melt degassing (Raimbault et al. 1995). This phenomenon, already cited in studies of other granites (Suzhou: Wang et al. 1996, Laoshan: Wang et al. 2000, 2001), may be described as follows:

$$
\begin{aligned}
& {\left[\mathrm{Zr}_{1-a-b-c} \mathrm{Hf}_{a} \mathrm{Y}_{b}(\mathrm{U}, \mathrm{Th})_{c}\right]\left(\mathrm{Si}_{1-b} \mathrm{P}_{b}\right) \mathrm{O}_{4} \rightarrow} \\
& \text { Zircon (Core of zircon) } \\
& \begin{array}{ccc}
\left.\mathrm{Zr}_{1-a-b-c-\mathrm{Hf}_{a}}\right) \mathrm{Si}_{1-b-c} \mathrm{O}_{4-4 b-4 c} & +b \mathrm{YPO}_{4}+c(\mathrm{U}, \mathrm{Th}) \mathrm{SiO}_{4} \\
\text { Hafnian zircon } & \mathrm{Xeno} & \text { Uranoan } \\
(\text { Rim of zircon) } & \text { time- }(\mathrm{Y}) & \text { thorite }
\end{array}
\end{aligned}
$$

In summary, observations based on accessory minerals point to a magmatic environment for the $\mathrm{G}-\mathrm{a}$ granite. In contrast, the $\mathrm{G}-\mathrm{b}$ and $\mathrm{G}-\mathrm{c}$ granites experienced a degassing process during their crystallization. Primary minerals such as yttrian fluorite and monazite-(Ce) may have broken down to secondary phases in fluid-rich environments. This type of late- to postmagmatic fluid must have been enriched in $\mathrm{F}$ and $\mathrm{CO}_{2}$, and derived from the final oversaturation of the granitic melt (Maruéjol et al. 1990). On the basis of results from mine geology, the mineralization in tungsten at Xihuashan is considered to be related to the granites G-b and G-c (Hu et al. 1984, Li et al. 1986). Similarities regarding the nature of the ore-forming fluids in the Xihuashan tungsten deposit have been investigated by Giuliani et al. (1988). These authors have identified the earliest fluid phases as $\mathrm{CO}_{2}$-bearing aqueous solutions circulating at temperature up to $420^{\circ} \mathrm{C}$. The $\mathrm{CO}_{2}$-rich fluids played important role in the transport of the tungsten. The formation of the extensive tungsten mineralization in Xihuashan may be therefore interpreted to be caused by a stable and long-lasting flow of hydrothermal fluid through the granites.

Finally, we conclude that the pattern of evolution of $\mathrm{Y}, R E E, \mathrm{Zr}, \mathrm{U}$, Th and $\mathrm{Nb}$ in the Xihuashan pluton was a complex, multi-stage process, and involved primary magmatic crystallization and late-stage hydrothermal alteration.

\section{ACKNOWLEDGEMENTS}

Financial support for this work was provided by the Natural Science Foundation of China (40025209 and 40221301) and by the Chinese Ministry of Education (2000028431). Comments by Alexander U. Falster,
Robert F. Martin, William B. Simmons Jr. and Michael A. Wise significantly improved the manuscript.

\section{REFERENCES}

ÅMLI, R. \& GRIFFIN, W.L. (1975): Microprobe analysis of REE minerals using empirical correction factors. Am. Mineral. 60, 599-606.

Ayers, J.C. \& Watson, E.B. (1991): Solubility of apatite, monazite, zircon, and rutile in supercritical aqueous fluids with implication for subduction zone geochemistry. Phil. Trans. R. Soc. Lond. A 335, 365-375.

BEA, F. (1996): Residence of REE, Y, Th and U in granites and crustal protoliths: implications for the chemistry of crustal melts. J. Petrol. 37, 521-552.

Broska, I., Petrík, I. \& Williams C.T. (2000): Coexisting monazite and allanite in peraluminous granitoids of the Tribeč Mountains, Western Carpathians. Am. Mineral. 85, 22-32.

ČERNÝ, P. \& HAWTHORNE, F.C. (1982): Selected peraluminous minerals. In Granitic Pegmatites in Science and Industry (P. Černý, ed.). Mineral. Assoc. Can., Short-Course Handbook 8, 163-186.

Correia Neves, J.M., Lopes Nunes, J.E. \& Sahama, T.G. (1974): High hafnium members of the zircon-hafnon series from the granitic pegmatites of Zambezia, Mozambique. Contrib. Mineral. Petrol. 48, 73-80.

Cuney, M. \& Brouand, M. (1987): Minéralogie et géochimie de U et Th dans le granite de Beauvoir et les micaschistes encaissants. Comparaison avec la géochimie de l'étain. Géol. France 2-3, 247-257.

\& FRIEDERICH, M. (1987): Physicochemical and crystal-chemical controls on accessory paragenesis in granitoids: implications for uranium metallogenesis. Bull. Minéral. 110, 235-247.

Marignac, C. \& Weisbrod, A. (1992): The Beauvoir topaz-lepidolite albite granite (Massif Central, France): the disseminated magmatic $\mathrm{Sn}-\mathrm{Li}-\mathrm{Ta}-\mathrm{Nb}-\mathrm{Be}$ mineralization. Econ. Geol. 87, 1766-1794.

DAHLQUIST, J.A. (2001): REE fractionation by accessory minerals in epidote-bearing metaluminous granitoids from the Sierras Pampeanas, Argentina. Mineral. Mag. 65, 463-475.

FÖRSTER, H.-J. (1998a): The chemical composition of REEY-Th-U-rich accessory minerals in peraluminous granites of the Erzgebirge-Fichtelgebirge region, Germany. I. The monazite-(Ce) - brabantite solid-solution series. Am. Mineral. 83, 259-272.

(1998b): The chemical composition of REE-Y-ThU-rich accessory minerals in peraluminous granites of the Erzgebirge-Fichtelgebirge region, Germany. II. Xenotime. Am. Mineral. 83, 1302-1315. 
Giuliani, G., LI, Y.D. \& ShEnG, J.F. (1988): Fluid inclusion study of Xihuashan tungsten deposit in the southern Jiangxi province, China. Mineral. Deposita 23, 24-33.

Hickmott, D.D., Shimizu, N., Spear, F.S. \& Selverstone, J. (1987): Trace-element zoning in a metamorphic garnet. Geology 15, 573-576.

Hsu, Ke-ChIN (XU, K.Q.) (1943): Tungsten deposits of southern Kiangsi, China. Econ. Geol. 38, 431-474.

Hu, S., Sun, M., Yan, Z., Xu, J., CaO, X. \& Ye, Y. (1984): An important metallogenetic model for $\mathrm{W}, \mathrm{Sn}$ and rare granophile element deposits related to metasomatically altered granites. In Geology of granites and their metallogenetic relations (K.Q. Xu \& G.C. Tu, eds.). Science Press, Beijing, People's Republic of China (519-537).

Huang, Xiao Long, Wang, Ru Cheng, Chen, Xiao Ming, Hu, HUAN \& LIU, CHANG SHI (2002): Vertical variations in the mineralogy of the Yichun topaz-lepidolite granite, Jiangxi Province, southern China. Can. Mineral. 40, 1047-1068.

JAFFE, H.W. (1951): The role of yttrium and other minor elements in the garnet group. Am. Mineral. 36, 133-155.

JAROSEWICH, E. \& BoATNER, L.A. (1991): Rare-earth element reference samples for electron microprobe analysis. Geostandards Newslett. 15, 397-399.

LANZIROTTI, A. (1995): Yttrium zoning in metamorphic garnets. Geochim. Cosmochim. Acta 59, 4105-4110.

Le Bel, L., LI, Yi-Dou \& Sheng, Ji-Fou (1984): Granitic evolution of the Xihuashan-Dangping (Jiangsi, China) tungsten-bearing system. Tschermaks Mineral. Petrogr. Mitt. 33, 149-167.

Li, Yi-Dou, Sheng, Ji-Fou, Le Bel, L. \& Giuliani, G. (1986): Evidence for the lower continental crustal source of the Xihuashan granite. Acta Geol. Sinica 60(3), 256-274.

LINNEN, R.L. (1998): The solubility of Nb-Ta-Zr-Hf-W in granitic melts with $\mathrm{Li}$ and $\mathrm{Li}+\mathrm{F}$ : constraints for mineralization in rare metal granites and pegmatites. Econ. Geol. 93, 1013-1025.

LIU, W.X. (1990): Geological and Geochemical Study of the Xianghualing Rare-Metal Granite, Hunan Province. M.S. report, Nanjing University, Nanjing, China.

LUMPKIN, G.R. (1998): Rare-element mineralogy and internal evolution of the Rutherford \#2 pegmatite, Amelia County, Virginia: a classic locality revisied. Can. Mineral. 36, 339353.

MaruéJol, P., Cuney, M. \& Turpin, L. (1990): Magmatic and hydrothermal R.E.E. fractionation in the Xihuashan granites (SE China). Contrib. Mineral. Petrol. 104, 668-680.

McKee, E.H., Rytuba, J.J. \& Xu, Ke-QIN (1987): Geochronology of the Xihuashan composite granitic body and tungsten mineralization, Jiangxi Province, South China. Econ. Geol. 82, 218-223.
PYLE, J.M. \& SPEAR, F.S. (1999): Yttrium zoning in garnet: coupling of major and accessory phases during metamorphic reactions. Geol. Mat. Res. 1, 1-49.

Raimbault, L., Cuney, M., Azencott, C., Duthou, J.-L. \& JORON, J.-L. (1995): Geochemical evidence for a multistage magmatic genesis of Ta-Sn-Li mineralization in the granite at Beauvoir, French Massif Central. Econ. Geol. 90, $548-576$

RAPP, R.P. \& WATSON, E.B. (1986): Monazite solubility and dissolution kinetics: implications for the thorium and light rare earth geochemistry of felsic magmas. Contrib. Mineral. Petrol. 94, 304-316.

Robinson, D.M. \& MiLleR, C.F. (1999): Record of magma chamber processes preserved in accessory mineral assemblages, Aztec Wash pluton, Nevada. Am. Mineral. 84, 1346-1353.

RoEDER, P.L. (1985): Electron-microprobe analysis of minerals for rare-earth elements: use of calculated peak-overlap corrections. Can. Mineral. 23, 263-271.

Shen, Wei-Zhou, Xu, Shi Jin, Wang, Yin-Xi \& YAng, JieDong (1994): Study on the Nd-Sr isotope of the Xihuashan granite. Chin. Sci. Bull. 39, 653-657.

Stowell, H.H., Menard, T. \& Ridgway, C.K. (1996): Cametasomatism and chemical zonation of garnet in contactmetamorphic aureoles, Juneau gold belt, southeastern Alaska. Can. Mineral. 34, 1195-1209.

UHER, P. \& ČERNÝ, P. (1998): Zircon in Hercynian granitic pegmatites of the western Carpathians, Slovakia. Geol. Carp. 49, 261-270.

Wakita, H., Shibao, K. \& Nagashima, K. (1969): Yttrian spessartine from Suishoyama, Fukushima Prefecture, Japan. Am. Mineral. 54, 1678-1683.

Wang, Ru Cheng, Fontan, F. \& Monchoux, P. (1992): Minéraux disséminés comme indicateurs du caractère pegmatitique du granite de Beauvoir, Massif d'Échassières, Allier, France. Can. Mineral. 30, 763-770.

Xu, Shi Jin, Chen, Xiao Ming \& MonchouX, P. (1996): Hafnian zircon from the apical part of the Suzhou granite, China. Can. Mineral. 34, 1001-1010.

Wang, D.Z., Zhao, G.T., Lu, J.J., Chen, Xiao MING \& XU, SHI JIN (2001): Accessory mineral record of magma-fluid interaction in the Laoshan I- and A-type granitic complex, Eastern China. Phys. Chem. Earth A 26, 835-849.

Zhao, G.T., Lu, J.J., Chen, Xiao Ming, Xu, Shi Jin \& WANG, D.Z. (2000): Chemistry of Hf-rich zircons from the Laoshan I- and A-type granites, eastern China. Mineral. Mag. 64, 867-877.

WARK, D.A. \& Miller, C.F. (1993): Accessory mineral behavior during differentiation of a granitic suite: monazite, 
xenotime, and zircon in the Sweetwater Wash pluton, southeastern California, U.S.A. Chem. Geol. 110, 49-67.

WiLliams, C.T. (1996): Analysis of rare earth minerals. In Rare Earth Minerals: Chemistry, Origin and Ore Deposits (A.P. Jones, F. Wall \& C.T. Williams, eds.). Chapman and Hall, London, U.K. (327-348).

Williams-Jones, A.E. \& Wood, S.A. (1992): A preliminary petrogenetic grid for REE fluorocarbonates and associated minerals. Geochim. Cosmochim. Acta 56, 725-738.

Xu, SHI JIN (1986): Rare-Earth-Element Geochemistry and Petrogenesis of Rare-Metal Granitoids in South China. Ph.D thesis, Nanjing University, Nanjing, China.

Yin, Lin, Pollard, P.J., Hu, SHOU-XI \& TAYloR, R.G. (1995): Geologic and geochemical characteristics of the Yichun $\mathrm{Ta}-\mathrm{Nb}-\mathrm{Li}$ deposit, Jiangxi Province, South China. Econ. Geol. 90, 577-585.

Zhu, Jin-Chu, Li, Ren-Ke, Li, Fu-Chun, Xiong, Xiao-Lin, Zhou, Feng-Ying \& HuAng, XIAO-Long (2001): Topaz- albite granites and rare-metal mineralization in the Limu district, Guangxi Province, southeast China. Mineral. Deposita 36, 393-405.

\& LiU, W.X. (1990): Topazite-ongonite relationship and its bearing on vertical zonation in rare-metal granites: evidence from Xianghualing district, Hunan Province, China. Proc. $8^{\text {th }}$ Quadrennial IAGOD Symp. (Stuttgart), 303-313.

ZIMMER, P. (1986): Étude expérimentale à haute température et haute pression du système ternaire $\mathrm{UO}_{2}-\mathrm{ThO}_{2}-\mathrm{SiO}_{2}$, en présence d'une phase fluide. Comparaison avec les systèmes $\mathrm{ZrO}_{2}-\mathrm{ThO}_{2}-\mathrm{SiO}_{2}$ et $\mathrm{UO}_{2}-\mathrm{ZrO}_{2}-\mathrm{SiO}_{2}$. Implications géologiques. Géol. Géochim. Uran. Mém. (Nancy) 12.

Received July 14, 2002, revised manuscript accepted April 17, 2003. 